E.L.U.A., 1, 1983, págs. 25-88

\title{
LOS UNIVERSALES DEL LENGUAJE: EL CICLO TRANSFORMATORIO Y LA «RULE OF TREE-PRUNING»
}

\author{
Manuel Crespillo \\ (Universidad de Málaga)
}

La identidad entre el lenguaje, el pensamiento y la realidad convierte al pensamiento clásico en una estructura circular donde la dualidad "sujeto/objeto" desempeña una función primordial. En cuanto que caracterización global es innecesario comprobar la carencia de materialidad presente en los discursos que se derivan de este pensamiento, y, en cambio, sí resulta imprescindible comprender la dinámica histórica que recorren sus formulaciones categóricas. El dato más clarificativo viene dado por la continua instauración en el objeto de las categorías propias del sujeto, tanto en el empirismo anglosajón -en el que el objeto de conocimiento es siempre la abstracción de un sujeto-, como en el criticismo de Kant - para quien el objeto racional de conocimiento es una categoría pura del sujeto-, como en la fenomenología de Husserl -en la que el objeto formal se constituye mediante la esencia lógica y trascendente del sujeto.

La primera temática categórica del sujeto se lleva a cabo a través del cogito cartesiano durante una coyuntura histórica en la que comienza a delimitarse una supremacía del nivel privado del sujeto sobre el nivel público que había imperado durante todo el orden feudal. En el Discurso del método, el miedo al error y el rechazo de los sentidos facilitan la búsqueda de un criterio de certeza capaz de funcionar como

(1) Cf. M. CRESPILLO (1980b). 
un "verdadero método" (2). Desde su formulación inicial, el sujeto se manifiesta escindido en espíritu y extensión, y la razón es una categoría verdadera, universal y perfecta: verdadera, porque la mente se destaca pronto como una facultad infalible que contrasta con el «engaño de la existencia" (3); universal, porque existe una unidad de la razón fundamentada sobre suposiciones que lógicamente parecen verosímiles si se tiene en cuenta que «el buen sentido es la cosa mejor repartida del mundo" ya que "la potencia de bien juzgar y de distinguir lo verdadero de lo falso [...] es, por naturaleza, igual en todos los hombres" (4), y, perfecta, porque constituye un reflejo de la unidad de la razón (5). Apenas se concibe la mente humana como una unidad más clara que la res extensae ya se está provocando una estructura circular en la escisión misma del sujeto (6). Esta es la causa de la aparente irreductibilidad entre el cuerpo y el alma: la distinción "alma indivisible/alma divisible" así como la hegemonía cognoscitiva que el alma ejerce sobre el cuerpo logran la ficción de una separación tajante entre el espíritu y la materia (7). Pero no deja de ser una paradoja que el sujeto escindido en

(2) Cf. R. DESCARTES (1968, 120-121): “Puesto que hay hombres que se equivocan al razonar, incluso acerca de las más simples razones de la geometría, y cometen en ellas paralogismos, pensé que yo estaba tan expuesto a equivocarme como cualquier otro [...] Mientras queria pensar asi que todo era falso, era preciso, necesariamente, que yo, que to pensaba, fuese alguna cosan, y al observar que 'yo pienso, yo existo' era una verdad firme y segura apensé que podia admitirla sin escrúpulo como el primer principio de la filosofía que buscabam.

(3) Cf. R. DESCARTES (1973, 64-65): «No admito que exista otra cosa en mí a excepción de la menten; «me doy clara cuenta de que nada absolutamente puede ser conocido con mayor facilidad y evidencia que mi mente". Cf. R. Descartes (1968, 92-93, 122 y 129-132): el espíritu humano puede encontrar una verdad en cada cosa mediante la razón porque ésta uno nos dice que lo que vemos o imaginamos asi sea verdadero, pero si nos dice que todas nuestras ideas o nociones han de tener algún fundamento de verdad".

(4) Cf. R. DESCARTES (1968, 59-60).

(5) Cf. R. DESCARTES (1968, 78-80). No hay tanta excelencia «en las obras compuestas de diversas piezas y hechas por las manos de diversos maestros como en las que han sido trabajadas por uno solow.

(6) Cf. A. DESCARTES $(1973,87)$ : "Con seguridad, mi idea de la mente humana, en tanto que es una cosa que piensa, no extensa a lo largo ni a lo ancho ni a lo profundo, y no teniendo parte alguna de cuerpo, es mucho más clara que la idea de cualquier otra cosa corporals.

(7) Cf. P. DESCARTES $(1973,121)$ : «Advierto, en primer lugar que hay una gran diferencia entre el alma y el cuerpo en el hecho de que el cuerpo sea siempre divisible por naturaleza y el alma indivisible [...] Finalmente, advierto que el alma no es impresionada de un modo inmediato por todas las partes del cuerpo, sino tan sólo por el cerebro, o quizá tan sólo por una exigua parte de aquél, es decir, por aquélla en la que se dice que está el sentido común". Esta aparente irreductibilidad exige la defensa de determinadas ideas religiosas, como el camino de la virtud, el tránsito a una vida futura, etc. Cf. R. DESCARTES (1968, 162-163). 
espíritu y extensión mantenga a su vez una relación de dependencia entre la res cogitans y la res extensae. Aunque el predominio de la mente en la fragmentación del sujeto permita afirmar a Descartes que todo lo que emana del cuerpo apenas es digno de mencionarse y que las cosas corpóreas existen no según como se conciben por los sentidos sino tal como se comprenden en el objeto de la pura matemática, resulta incomprensible su formulación del cogito sin un arraigo de la res extensae en la res cogitans, esto es, sin una dependencia mutua entre el espíritu y la extensión que implique la inscripción de las ideas en el pensamiento y la comprensión de la existencia en la idea (8). La subordinación e inclusión de la extensión en el espíritu estaba amparada por la actividad del sujeto que convertía lo inerte en inteligible: "existe en mí una cierta facultad pasiva de sentir, o de recibir y conocer las ideas de las cosas sensibles, pero no obtendría ningún provecho de ella si no existiese también una cierta facultad activa, ya exista en mí, ya en otro, de producir o de hacer estas ideas" (9).

La idea cartesiana se convierte en una cuestión decisiva y difícil en el discurso transformatorio. Chomsky se apoya en las Meditaciones metafísicas de Descartes: “'algunos de mis pensamientos son imágenes de las cosas y sólo a éstos se les puede aplicar con propiedad la denominación de idea' [...] estas 'imágenes' se pueden derivar de la imaginación o de la reflexión antes que recibir a través de la percepción» (10). Y también Chosmky se sustenta en la réplica de Descartes a la Objection de Hobbes: el término idea abarca cualquier cosa que la mente percibe directamente. Aunque Chosmky dice que este último uso de la idea como objeto de pensamiento es el que parece consistente con su utilización general, de hecho tanto la imaginación o la reflexión como la percepción directa conducen al único modo válido de conocimiento en el racionalismo: la intuición. La reflexión es la certeza que produce la intuición. Y un planteamiento paralelo cabe efectuar con la

(8) Cf. R. DESCARTES $(1973,64)$. Aunque en la historia de los discursos categóricos se insista con frecuencia en la escisión, Descartes es mucho más cauto. Cf. R. DESCARTES (1968, 125-127): "Yo tenía idea de diversas cosas sensibles y corporales, porque aun suponiendo que soñaba y que todo cuanto vela o imaginaba era falso, no podía, sìn embargo, negar que las ideas estuvieran verdaderamente en mi pensamiento [...] Si volvía a examinar la idea que tenía de un ser perfecto, encontraba que la existencia está comprendida en ella».'Del mismo modo, cf. R. DESCARTES $(1973,113)$ : "Por lo tanto, del hecho mismo de que yo sé que existo. y de que advierto que ninguna otra cosa en absoluto atañe a mi naturaleza o a mi esencia, excepto el ser una cosa que piensa, concluyo con certeza que mi existencia radica únicamente en ser una cosa que piensan.

(9) Cf. R. DESCARTES $(1973,114)$.

(10) Cf. N. CHOMSKY $(1966,83$, nota 70$)$. 
imaginación o la percepción: la mente imagina o percibe directamente mediante un conocimiento intuitivo forzado por la actividad del sujeto que busca lo inteligible que la sustancia contiene. La adscripción de Chomsky a la teoría cartesiana se explica con extrema facilidad si se tiene en cuenta que los primeros principios transformatorios se fundamentaron sobre límites diferenciados y alejados del empirismo estricto que dominaba el ámbito lingüístico americano. Precisamente la crítica empirista a la idea se centra sobre la sustancia inerte y olvida lo inteligible que en ella se contiene y, por tanto, toda la actividad del sujeto: la mente «posee poder para abstraer sus ideas, y así llegan a ser esencias, esencias generales mediante las que se distinguen las clasificaciones de las cosas" (11). Por eso Locke establece una ordenación y distinción de las sustancias atendiendo a sus esenciales nominales y no a sus esencias reales (12); Berkeley, aunque niega la extensión (13) — claro síntoma de su posterior viraje en Siris-, produce una profunda quiebra en la sustancia cartesiana, ya que "no hay otras sustancias sino las espirituales, esto es, las que son capaces de percibir" (14), y Hume, al encuadrar la idea dentro de la percepción sensible, sabe prescindir de la tesis cartesiana sobre las dos sustancias y sustituirla por la problemática más compleja de la causalidad de la naturaleza humana (15). La idea como objeto de pensamiento, como reflexión o percepción directa, que descansa en un argumento cartesiano bastante conocido (i. e. ciertas leyes que Dios ha establecido así en la naturaleza y cuyas ideas ha impreso en nuestras mentes), ha sido un comodín especulativo - la misma falta de claridad que Chomsky atribuía a Descartes-, dentro de la primera y de la segunda modalidad de los textos transformatorios (16): indica

(11) Cf. J. LOCKE $(1974,149)$.

(12) Cf. J. LOCKE $(1974,143)$ : «La medida y límites de cada clase 0 especie por lo que se constituye y se distingue de las demás es lo que llamamos esencia: es decir, la idea abstracta a la que el nombre está unido. A esto, aunque sea la esencia que conocemos de las sustancias naturales, lo llamo esencia nominal, para distinguirla de la constitución real de las sustancias, de la que depende esta esencia nominal y todas las propiedades de cada clase; esa constitución real, aunque desconocida, puede llamarse esencia real».

(13) C. G. BERKELEY $(1974,85)$ : «Lo único inadmisible y que niego absolutamente es la existencia de lo que los filósofos llaman materia o sustancia corpóream.

(14) Cf. G. BERKELEY (1974, 64): «Fijémonos en que las cualidades sensibles son el color, la figura, el movimiento, el olor, el sabor y otras, decir, las ideas percibidas por los sentidos. Ahora bien, puesto que es evidente contradicción el que exista una idea en un ser que no perciba, y ya que el tener ideas es lo mismo que percibir, y por lo tanto donde existe el color, figura, olor y demás cualrdades sensibles hay un ser que las percibe, de ello resulta claramente que no puede existir una sustancia impensante o sustratum de estas ideas".

(15) Cf. D. HUME (1973, 61-63).

(16) Es muy importante en este articulo la distinción que efectúo entre primera y segunda 
conceptos diversos que incluyen hasta proposiciones, o es un elemento del proceso mental cuya comprensión desempeña un papel crucial en la interpretación semántica (17), o es el eje determinante de un problema esencial para la semántica transformatoria: ¿pueden expresar las mismas ideas todas las lenguas? (18).

La concepción de la idea en los textos transformatorios contiene toda la amplitud de que goza el término en el racionalismo. Deleuze aclaró que en Descartes la suficiencia teórica de la idea clara y distinta -origen de la escisión y posterior dependencia del sujeto en «espíritu/extensión»-, se liga a la posibilidad práctica de ir de un conocimiento claro y distinto del efecto a un conocimiento claro y distinto de la causa, mientras que en Spinoza la suficiencia de la idea clara y distinta es imposible porque el recorrido del efecto a la causa es irrealizable. No es importante la idea clara y distinta sino la idea adecuada, ni tampoco la subordinación causal del efecto sino la dependencia que todo conocimiento del efecto tiene del conocimiento de la causa (19). El término conocimiento aplicado a la idea clara y distinta es el que establece la diferencia entre la sintesis de Spinoza y el análisis de

modalidad de los discursos transformatorios porque en la literatura transformatoria se suele hablar de modelos, y se distinguen más de dos. El criterio que utilizo para distinguir dos modalidades no consiste en un simple argumento empirico en el que el término modalidad sea sinónimo de modelo, propuesta, hipótesis, etc. Pues si así fuera habria que distinguir entre el modelo inicial de 1957 , la teoria normal de 1965, la teoría normal ampliada, las aportaciones que a estas dos últimas propuestas incorporan la hipótesis léxica y la hipótesis léxica extendida, y, finalmente, la gramática de casos y la semántica transformatoria. Mi tesis es puramente teórica, y en este sentido considero que no hay más que dos propuestas válidas dentro de las gramáticas transformatorias: una lectura sintáctica del sistema, que corresponderia a la primera modalidad, y una lectura semántica del mismo sistema, que perteneceria a la segunda. Primera y segunda modalidad no son nociones empíricas sino sintaxis y semántica 0 , por decirlo en términos categóricos, racionalismo y neopositivismo. Cf. M. CRESPILLO (1982).

(17) Cf. N. CHOMSKY $(1966,84$, nota $70 ; 100$, nota 85$)$ : la estructura profunda es fundamental en el análisis del pensamiento porque es un reflejo directo de los procesos mentales.

(18) Cf. J. D. McCAWLEY $(1967,532)$ : "Can all languages express the same ideas? One would be tempted to immediately answer ' $n o$ ', due to the obvious fact that languages often lack words for things unknown in the cultures in which they are spoken, e.g. Eskimo probably has no word for pachinko and Hottentot probably has no expression for 'third-baseman'. However, if one modifies the question slightly and asks whether all languages could express the same ideas if they were allowed to add words for all the things unknown in the cultures where they are spoken, the answer to the question ceases to be obvious. This question is of course closely related to question 4.». La pregunta 4 de McCawley era: "To what extent are the units of semantic representation universal? Are there atomic predicates which play a role in representing meanings in all languages? If symbolic logic is a valid means of representing meanings in English, is it also a valid means of representing meanings in all other languages? ".

(19) Cf. G. DELEUZE $(1968,134-135$ y 150-163). 
Descartes: conocer por la causa se convierte en el único medio de conocer la esencia. Ahora bien, en la medida en que se puede hablar de un anticartesianismo en Spinoza o en Leibnitz debe estar fundamentado en el término expresión (20). La única diferencia estriba en que para Spinoza la filosofía de la expresión es una filosofía de las expresiones univocas mientras que para Leibnitz es una filosofía de las expresiones equívocas. Por consiguiente, la razón, según Leibnitz, significa «algunas veces principios claros y verdaderos; otras, conclusiones deducidas de estos principios; y alguna vez la causa, y particularmente la causa final» (21). También los textos transformatorios contienen una filosofía de las expresiones equívocas y, como le sucedía a Leibnitz, la ambigüedad de las expresiones mantiene su coherencia mediante la razón (22). Esta coherencia rompe definitivamente la aparente irreductibilidad del cogito en espíritu y extensión mediante las mónadas (23). Los principios de las sustancias simples proporcionan «el medio de explicar naturalmente la unión o la conformidad del Alma y del cuerpo orgánico. El Alma sigue sus propias leyes, así como el cuerpo las suyas; y se encuentran en virtud de la Armonia preestablecida entre todas las sustancias, puesto que todas ellas son representaciones de un "mismo universo" (24). La Armonía preestablecida es el primer planteamiento moderno de la confusión explícita entre un discurso y su objeto, esto es, de la identificación entre el pensamiento y la realidad: la objeti-

(20) Tanto en uno como en otro el término expresión tiene tres dimensiones: la ratio essendi, dimensión teológica animada por el ser; la ratio agendi, dimensión ontológica animada por la acción y la ratio cognoscendi, dimensión gnoseológica animada por el conocimiento. Cf. G. DELEUZE (1968, 9-13 y 319-325).

(21) Cf. G. W. LEIBNITZ (1972a, 178 y 202-203): “Después de haber dicho algunas palabras sobre la relación de nuestra razón con los demás hombres, añadamos algo sobre su relación con Dios, que hace que distingamos entre lo que es contrario a la razón y lo que está por encima de la razón. De la primera clase es todo lo incompatible con nuestras ideas claras y distintas; de la segunda, todo sentimiento cuya verdad o probabilidad no vearos que pueda ser deducida de la sensación o de la reflexión por medio de la razón".

(22) Cf. G.W. LEIBNITZ (1973, 45): “de la misma manera que el todo es mayor que la parte es el principio de la aritmética y de la geometría, ciencias de la cantidad, asi también nada tiene lugar sin razón es el fundamento de la física y la moralm.

(23) Se trata de una aparente irreductibilidad porque la inteligibilidad de lo inerte siempre está implícita en Descartes. El Espíritu, el Alma, el Yo, e incluso Dios, como mónada increada, forman parte de la Armonia preestablecida. Cf. G. W. LEIBNITZ (1972b, 47, párrafo 62): «Aunque cada Mónada creada representa al universo entero, representa más distintamente el cuerpo que le afecta particularmente, y del cual constituye la Entelequia. Y como este cuerpo expresa todo el universo oor la conexión de toda la materia en lo lleno, el Alma representa, por consiguiente, todo el universo al representar al cuerpo que le pertenece de una manera particularn.

(24) Cf. G.W. LEIBNITZ (1972b, 52, párrafo 78). 
vidad del lenguaje y del conocimiento se concibe como una unión indisoluble entre el ser ideal de los conceptos o su verdad y el ser real de las cosas, y, consiguientemente, la Armonía prestablecida tiende un lazo de unión entre lo irreal y lo real, entre las verdades universales válidas y los entes particulares y fácticos. Esta integración absoluta entre el espiritu y su extensión es lo que determina el anticartesianismo de Leibnitz (25).

Este proceso equívoco de confusión entre un discurso y su objeto, esto es, el proceso de identificación entre un objeto producido y un objeto real (26), ha permitido que los textos transformatorios conviertan los universales del lenguaje en universales de gramática. El problema del sujeto universal, sometido a razonables procesos de reformulación, constituye uno de los legados más sugestivos que las dos modalidades de los discursos transformatorios han heredado del racionalismo moderno. En los textos cartesianos el lenguaje es un medio que refleja las propiedades lógicas atribuidas a la razón. Si la razón es universal, su medio también lo es. En esta propuesta radica el proyecto cartesiano de construir una lengua universal, proyecto que fue declarado explícitamente por Descartes en su carta a Mersenne (27). La transición al nuevo orden, en el que se inscribe Descartes, está impulsada por una teoría matemática de la naturaleza que se concibe como modelo de una sistematización lingüística: junto al postulado de la mathesis universalis aparece el principio de una lingua universalis y "asi como a partir de relativamente pocos signos numéricos puede construirse todo el sistema de la Aritmética, debería poderse designar también exhaustivamente la totalidad de los contenidos intelectuales y su estructura mediante un número limitado de signos lingüísticos, siempre que éstos sean enlazados de acuerdo con determinadas reglas universalmente válidas" (28). En la mathesis universalis cartesiana convergen la unidad

(25) Cf. G. W. LEIBNITZ (1972b, 53, párrafo 80): «Descartes ha reconocido que las Almas no pueden dar fuerza a los cuerpos, porque hay siempre la misma cantidad de fuerza en la materia. Ha creído, sin embargo, que el alma podía cambiar la dirección de los cuerpos. Pero esto era porque en su tiempo no se conocía la ley de la naturaleza que expresa la conservación de la misma dirección total en la materia. Si él se hubiera dado cuenta habría caído en mi Sistema de la Armonía preestablecida».

(26) Cf. M. CRESPILLO (1980b).

(27) Cf. E. LLEDO $(1970,35)$ y G. FANO $(1968,17)$.

(28) Cf. E. CASSIRER (1971, 75-76) y E. CASSIRER (1972, 16-25). «El ideal de la unidad del saber, de la sapientia humana que permanece siempre una y la misma sin importar cuántos objetos distintos pueda abarcar, es trasladado ahora al lenguaje». Del mismo modo que la forma fundamental una e idéntica de la razón humana se repite siempre en todos los conocimientos que verdaderamente tengan la pretensión de tales, todo tipo de habla debe basarse también en la única y universal forma racional del lenguaje». En los lenguajes 
del universo, la unidad del conocimiento del universo y la unidad de la lógica de este universo a través de la matemática universal. Esta triple unidad traduce la unidad de la materia y el espiritu en el cogito. También la mathesis universalis contiene una unidad universal que es la unicidad del "buen sentido" o de la "razón". Como decía Bajtin "el signo matemático es el que menos permite ser interpretado como expresión de la psiquis individual, y es precisamente el signo matemático el que los racionalistas consideran el ideal de todo signo, incluido el verbal» (29). La Lingua characteristica universalis de Leibnitz pone de manifiesto el valor primordial de este signo matemático y concibe el lenguaje como un instrumento del análisis lógico (30). Sin embargo, Leibnitz entiende la lógica a través de una recomposición de la mathesis universalis cartesiana, pues el proceso de reducción entre el espiritu y la extensión no se hace atendiendo al origen divino común de ambas sustancias, sino a través de un planteamiento filosófico en el que el espíritu se determina mediante una gradación de conocimientos asignada a las mónadas, esto es, a ciertas unidades sustanciales que establecen sus diferencias según su representación y de acuerdo con el grado de diversidad de sus contenidos representativos. La Característica universal determina la totalidad de las mónadas, y a su vez queda determinada por la unidad representativa de éstas (31). La mathesis

artificiales «siempre se parte de la idea de que hay un número limitado de conceptos tales que cada uno de ellos se encuentre con el otro en una conexión material determinada, en una relación de coordinación, supra o subordinación y que, además, el objetivo de un lenguaje verdaderamente perfecto debe consistir en expresar adecuadamente en un sistema de signos esta jerarquía natural de los conceptos. Asi, por ejemplo, Delgarno en su Ars Signorum, partiendo de estos presupuestos, ordena todos los conceptos bajo diecisiete conceptos genéricos supremos".

(29) Cf. M.M. BAJTIN $(1976,76)$.

(30) Los filosofos interpretan esta actitud como un preludio de la lógica moderna. Cf. E. LLEDO $(1970,36)$ y E. CASSIRER (1971, 77-81). Sólo Leibnitz, dirá Cassirer, "que sitúa de nuevo el problema del lenguaje dentro del concepto de la Lógica general y concibe a ésta como presupuesto de toda filosofía y todo conocimiento térico en general, capta también con una nueva profundidad el problema de la lengua universal». Asi como el análisis algebraico enseña que cada número se descompone en "números primos», también el contenido cognoscitivo se descompone en ideas primitivas. Ambas descomposiciones se llevan a cabo con un mismo método, pues Leibnitz resuelve la contradicción de que la forma de una característica universal presuponga como ya dado el saber y que además sea lo que permita conocer ese saber, diciendo que está pensada en una pura correlación material. La actitud racionalista permanece inalterable, pues del mismo modo que la algoritmia del cálculo diferencial se convierte en un órgano de la investigación matemática, el lenguaje debe preparar el pensamiento y seguir las partes de éste.

(31) Cf. E. CASSIRER (1971, 80-81): «Si el objetivo de la Característica universal estuviera logrado, si cada idea simple estuviera expresada mediante un simple signo sensible y cada representación compleja mediante una correspondiente combinación de tales signos, toda 
cartesiana, o la tesis de Leibnitz —según la cual el lenguaje que sirve a la razón es en sí mismo un conocimiento-, implican una terapéutica del lenguaje que está presta para confundir un objeto producido con un objeto real y para dotar de características universales no sólo a una posible lengua artificial sino incluso a la propia gramática. Una lengua universal podría ser el oscuro deseo escondido de la gramática universal que tanto ansían los discursos transformatorios. El propio Chosmky ha afirmado que debe aceptarse como un lugar común el hecho de que esta gramática tenga orígenes cartesianos. La escuela de Port-Royal, en el marco de esta lingüística cartesiana, se dedicó no sólo al estudio de la gramática general - ciencia destinada a estudiar los principios universales de la estructura del lenguaje-, sino también al análisis de la gramática particular - la cual se concebía como un arte antes que como una gramática descriptiva-, y pudo completar los mecanismos explicativos de una lengua universal que desconocían Descartes o Leibnitz.

Pero el proceso de identidad "discurso/objeto" contiene el signo de la repetición: la gramática transformatoria moderna es una respuesta al problema del sujeto universal originado en la doctrina de Port-Royal, $y$, lo que es más importante aún, sigue el modelo empirista del conocimiento, esto es, un sujeto y un objeto existen de antemano al proceso de conocer y el conocimiento está ya presente en el objeto porque aquél -el objeto de conocimiento-, es una parte de éste -el objeto real-. En el empirismo estricto el ojo que ve o percibe es el fundamento de cualquier lectura o conocimiento. Locke se verá obligado a manifestar que la percepción es la primera facultad de la mente que se ejerce sobre nuestras ideas, es decir, la primera operación de todas nuestras facultades intelectuales. Por eso no habla de ideas claras y distintas sino de ideas determinadas o definidas asignadas a un sujeto que puede ser visto y percibido. Como el entendimiento conoce mediante abstracciones extraídas de la percepción, la imperfección de las palabras reside en las ideas que representan y no en su incapacidad para entender (32). En Hume, la percepción sensible se manifiesta me-

particularidad y accidentalidad de los lenguajes aislados se volvería a disolver en un único lenguaje fundamental universals.

(32) Cf. J. LOCKE (1974, 23-24, 69-73 y 151-155): «Como el gran desorden que existe en nuestros nombres de las sustancias procede en su mayor parte de nuestro deseo de conocimiento y de nuestra incapacidad para penetrar en su constitución real, extrañará que atribuya esta imperfección más a las palabras que al entendimienton. Locke afirma también que "cuando examiné el origen y composición de nuestras ideas y la certeza y la extensión de nuestro conocimiento, halle todo ello tan enlazado con las palabras, que sólo si su significación era bien observada se podría saber algo sobre el entendimientom. Por eso dice 
diante impresiones e ideas. Las impresiones son las percepciones que el ojo siente penetrar con más fuerza y violencia en la mente humana, esto es, todas las sensaciones, emociones y pasiones según hacen su primera aparición en el alma. Las ideas son imágenes débiles que las impresiones provocan en el pensamiento y en la razón. Puesto que el ojo contiene una percepción neutra, las percepciones procedentes de la vista o del tacto - que pueden proporcionar un placer o un desasosiego inmediatos-, quedarán excluidas de las ideas, que son únicamente representaciones o copias de las impresiones (33). Lo mismo que sucedía en Locke, el sujeto psicológico de Hume, es también incapaz de conocer. El sujeto de Locke, que tomaba posesión previa de la razón, conoce mediante percepciones, y el sujeto de Hume conoce a través de impresiones o ideas sensibles. Ahora bien, lo que define como empirista a este proceso de conocimiento no es la existencia previa del sujeto y del objeto sino cierta relación que define al conocimiento en función del objeto real y que se centra en una operación de abstracción del sujeto: conocer es abstraer la esencia del objeto real mediante un procedimiento de extracción, cuya posesión se denomina conocimiento (34). Las palabras, dice Locke, tienen su origen en las ideas sensibles, y de ideas sensibles se transforman en significaciones abstractas que representan nuevas ideas que no caen bajo el dominio de nuestros sentidos: "las palabras son generales cuando se hacen signos de ideas generales; $y$ las ideas se hacen generales cuando se las separa de las circunstancias de tiempo y lugar y de toda otra idea que pueda determinarlas. Mediante esta abstracción se hacen capaces de representar más de una cosa individual" (35).

La clave del proceso empirista por el que un sujeto conoce a su objeto es la extracción y abstracción de la idea oculta en los cuerpos sensibles. Este conocimiento empirista lleva el rótulo "empirista" por comodidad terminológica, pues no hace alusión exclusiva al empirismo estricto sino a todas las formas del idealismo filosófico y, por tanto, es una categoria válida para el racionalismo o el neopositivismo implícitos en los textos transformatorios, por más que éstos entiendan la abstracción como innata al sujeto o al constructor de la teoría, que a su vez

E. Cassirer $(1978,81)$ que para Locke "la pregunta por la significación y origen de los conceptos no podía desvincularse de la pregunta por el origen de las denominaciones".

(33) Cf. D. HUME (1973, 79-80).

(34) Cf. L. ALTHUSSER y E. BALIBAR (1969, 40-46).

(35) Cf. J. LOCKE $(1974,136$ y 140). 
dejan de ser neutrales y son activos. Por eso dentro del ámbito lingüístico la búsqueda de los universales del lenguaje por parte de los discursos transformatorios constituye el esfuerzo más considerable de cuantos han puesto en práctica el modelo empiriśta de conocimiento. Puede suceder que el lenguaje sea un instrumento de la razón, cuya esencia se contenga en el espíritu de cada sujeto, que a su vez poseen un conocimiento innato de los principios universales del lenguaje. En este caso, la gramática general estudia las condiciones universales que prescriben la forma de cualquier lenguaje humano y que proporcionan los principios organizativos -atribuidos a la mente como propiedad innata- que permiten el aprendizaje lingüístico (36). Pero cabe también la posibilidad de que el lenguaje, al expresar todos los conceptos que el conocimiento contiene, se constituya en, el propio conocimiento. Entonces las verdades universales tienen un determinado carácter lógico y se extraen de múltiples sentidos particulares, ya que las características generales de la estructura gramatical son comunes a todas las lenguas y reflejan las propiedades fundamentales de la mente. Evidentemente, no es necesario que los universales se encuentren en todas las lenguas, pues es suficiente con que cada idioma lleve a cabo una selección particular de entre el sistema universal de las verdades del espíritu.

A partir de esta concepción empirista del conocimiento que lleva a cabo la confusión "discurso/objeto", los textos transformatorios consideran que los universales del lenguaje son universales de gramática (37). En la primera modalidad de los discursos transformatorios la

(36) Cf. J. LYONS $(1970,117)$ y N. CHOMSKY (1968a, 157-158). Dice N. Chosmky (1966, 124-125) que «al aproximarse de este modo a la cuestión de la adquisición del lenguaje y de los universales lingüísticos, la lingüística cartesiana refleja la preocupación de la psicologia racional del siglo XVII con la contribución de la mente al conocimiento humano". D. McNeill (1970, 534-535) recuerda que Schlesinger y Sinclair de Zwart opinan que la estructura subyacente de las oraciones está determinada por la capacidad cognoscitiva innata del niño y que los universales lingüisticos existen previamente porque las estructuras de pensamiento son universales. Tanto uno como otro, estudiando estructuras abstractas como el concepto de oración, creen que la influencia del conocimiento es visible en la estructura universal subyacente del lenguaje. El propio McNeill asume esta propuesta: «sweeping remarks, that all universals of language are in reality universals of cognition, cross the line separating science from dogma".

(37) Incluso fuera del dominio estricto de la lingüistica transformatoria se producen planteamientos similares. Un ejemplo destacable es la Conferencia sobre los Universales del Lenguaje del año 1961, que tuvo lugar en Nueva York, y cuyas ponencias han sido muy divulgadas a través de la edición de Greenberg. Los especialistas que intervinieron ejercian actividades interdisciplinarias: antropología, filosofía, psicología, lingüística, informática. J.H. Greenberg, Ch., E. Osgood y J.J. Jenkins (1963) decían en el Memorandum que precede a la edición de las ponencias que los universales lingüísticos están estrechamente ligados a 
gramática universal es un medio para resolver el problema general de la correspondencia entre un sonido y su significado. Según Chosmky, todo examen de las propiedades del lenguaje comprende tres partes: "el estudio de la fonética universal, el de la semántica universal y el del sistema, supraordenado a los anteriores, de la gramática universal. Los dos primeros implican la representación de la forma idealizada y del contenido semántico; la teoria de la gramática universal trata de los mecanismos que usan las lenguas humanas para determinar la forma de una oración y su contenido semántico» (38). La teoría de la fonética universal se propone establecer un alfabeto fonético universal y un sistema de leyes fonéticas. El alfabeto define el conjunto de las señales posibles del que se extraen las señales de cada lengua determinada, y sus símbolos no son los sonidos sino los rasgos distintivos, esto es, un sistema de generalizaciones fónicas - similar a las correlaciones establecidas por Jakobson-, que constituyen sus leyes. La semántica universal también está compuesta por un sistema universal de rasgos semánticos y por unas leyes relativas a sus relaciones mutuas y a los límites que se ponen a su diversidad. Si se dispone de teorias satisfactorias sobre la fonética y la semántica universales, puede definirse la lengua como «un conjunto de oraciones, siendo una oración un tipo determinado de par sonido - significado, y pasarse al estudio de los sistemas de reglas que definen a las lenguas humanas» (39). Del mismo modo, la gramática universal es "el estudio de las condiciones que deben satisfacer las gramáticas de todas las lenguas humanas. La semántica y la fonética universales, en el sentido antes apuntado, formarian entonces parte de la gramática universal. La gramática universal asi definida no es otra cosa que la teoría de la estruc-

principios psicológicos subyacentes -estudiados por la psicolingüística-, y a la cultura humana en general -estudiada por la etnolingüistica- En particular, la ponencia de J.H. Greenberg $(1963,73-114)$ se ceñía al orden de ciertos elementos significativos en los universales de gramática. Confundiendo el discurso con su objeto, este lingüista formuló siete universales tipológicos, dieciocho universales sintácticos y veinte universales morfologicos. Los universales tipológicos se regian por seis tipos comunes a todas las lenguas: VSO, SVO, SOV, VOS, OSV y OVS. El universal número tres es un ejemplo de universal tipológico: "Languages with dominant VSO order are always prepositional". El universal doce es un caso de universal sintáctico: alf a language has dominant order VSO in declarative sentences, it always puts interrogative words or phrases first in interrogative word questions; if it has dominant order SOV in declarative sentences, there is never such an invariant rulew. El universal treinta y seis era una clase de universal morfológico: alf a language has the category of gender, it always has the category of numbern. Otras ponencias importantes son las de R. Jakobson (1963, 263-278). Ch. E. Osgood (1963, 299-323), V. Weinreich $(1963,142-216)$ y S. Ulmann $(1963,217-263)$.

(38) Cf. N. CHOMSKY (1967a, 281-282).

(39) Cf. N. CHOMSKY (1967a, 286). 
tura lingüística» (40). Una gramática universal que se propone caracterizar la asociación intrínseca de la forma fonética y el contenido semántico de una lengua determinada puede llamarse, dice Chosmky, gramática generativa, la cual generará un conjunto de descripciones estructurales, a cada una de las cuales corresponde, idealmente, una estructura profunda, una estructura superficial, una interpretación semántica (de la estructura profunda) y una interpretación fonética (de la estructura superficial), y se distinguirá de aquellas descripciones que tienen algún otro objetivo (por ejemplo, las gramáticas pedagógicas) (41). La identidad “discurso/objeto» permuta el deseo racionalista de una lengua universal por el de una gramática universal, a la que otras veces se llama "mecanismo", "teoría de la estructura lingüistica", "sistema de reglas", etc. En la primera modalidad transformatoria el nivel de análisis constituido por la sintaxis dicta la verdad de la gramática, pues gramática universal y sintaxis universal son términos sinónimos. Así como el lenguaje universal expresa lo más puro del espíritu humano, la sintaxis es el mecanismo que explica la constitución de la naturaleza humana. Propiciado por la identidad «discurso/objeto", la sintaxis es un medio de expresión del espíritu, esto es, el nombre de la razón y el único mecanismo del modelo que es capaz de formar una lengua. ¿Cómo se podría concebir la existencia de las lenguas sin la presencia activa de la razón o del espíritu? La escisión del espíritu en cuerpo y alma y la cuestión de su reducimiento se traduce a la gramática universal como el problema general de la correspondencia entre el sonido y el significado. Asi se perpetúa una tesis central de todo el pensamiento clásico: el significado es el alma de las palabras y la forma su cuerpo. Lo mismo que la razón se escinde en extensión y espíritu, también la sintaxis, sedimento de la mente humana creativa, se interpreta mediante la fonética y la semántica universales. Esta búsqueda de los universales del lenguaje tampoco sufre variaciones sensibles en el análisis semántico del sistema que da lugar al nacimiento de la semántica transformatoria, pues para la técnica neopositivista la confusión "discurso/objeto" se origina a partir de la tesis crucial de que el lenguaje es el significante máximo del espíritu. Los universales del lenguaje están estrechamente ligados a las representaciones semánticas, que son traducciones al ámbito lingüístico de los predicados de la lógica simbólica (42).

(40) Cf. N. CHOMSKY $(1967 a, 288)$.

(41) Cf. N. CHOMSKY (1967a, 285-290) y N. CHOMSKY 1967b, 134).

(42) Cf. J. SEARLE $(1969,119)$ : "To understand the name of a universal it is necessary to understand the use of the corresponding general term. But the converse is not the case. 'Kindness' is parasitic on 'is kind': 'is kind' is prior to 'kindness'. A language could not 
¿Cómo se inicia en los textos transformatorios el estudio sobre los universales lingüísticos? Katz y Postal (1964) y Chosmky (1965) plantean casi simultáneamente la utilidad de clasificar los universales lingüísticos en universales sustantivos y formales (43). Dice Chosmky que la gramática general de Port Royal era una teoría de los universales sustantivos porque no sólo propuso ideas interesantes sobre la naturaleza de la fonética general o universal sino que también adelantó la posición de que se pueden encontrar ciertas categorías sintácticas fijas (nombre, verbo, etc.), en las representaciones sintácticas de las oraciones de cualquier lengua y, consiguientemente, proporcionan la estructura sintáctica subyacente general de cada lengua. Por tanto, toda teoría de los universales sustantivos sostiene que «los elementos de cierto tipo en cualquier lengua deben ser extraídos de una clase de elementos fija" (44). En cambio, los universales formales son más abstractos: "the distinction between substantive and formal universals is intended to correspond to the distinction between the form of such statements and their content» (45). Si se parte de la hipótesis de que la gramática de

contain the notion of 'kindness' unless it contained an expression having the function of 'is kind', but it could contain 'is kind' without kindness. This priority of predicate expressions over property names is shown by the fact that we could imagine a language capable of making statements (and performing other illocutionary acts) which contained only expressions used to refer to particulars and inflected predicate expressions-but not one which contained only expressions used to refer to particulars and expressions used to refer to properties. We could speak a language containing expressions like 'Socrates' and 'this rose' along with 'is a man', and 'is red', but not one which along with the former contained only expressions like 'wisdom', 'redness'. We could not even teach these latter expressions unless our student already understood what it was to be red or to be wise; and to understand these is just to understand the use of the corresponding predicates".

(43) Cf. N. CHOMSKY (1965, 27-30) y J.J. KATZ and P.M. POSTAL (1964, 159-166). Katz y Postal mencionan que uno de los aspectos esenciales que forman parte de la noción ulinguistic description of a natural languages» es "that part which concerns features common to all natural languages". $Y$, como el propio Chomsky, sostienen que junto a los universales formales y sustantivos, la teoria de la descripción lingüistica contiene ca specification of the form of each of the three components», esto es, . $\alpha$ a specification of the interconnections between the three components of any particular linguistic description".

(44) Cf. N. CHOMSKY $(1965,28)$. Por ejemplo, la teoría de los rasgos distintivos de $R$. Jakobson puede interpretarse como una aserción sobre los universales sustantivos del componente fonológico de una gramática. Cada output de dicho componente consta de elementos que se caracterizan mediante un número reducido de rasgos fónicos, universales y fijos, cada uno de los cuales tiene una característica acústico-articulatoria sustantiva independiente de cualquier lengua concreta. Una teoria de los universales sustantivos podrá sostener que ciertas funciones designativas pueden realizarse en cada lengua de un modo específico. Cada lengua tendrá términos que designen personas o unidades léxicas que se refieren a ciertos tipos especificos de objetos, sentimientos, conducta y demás.

(45) Cf. J.J. KATZ and P.M. POSTAL (1964, 160). 
todas y cada una de las lenguas cumple ciertas condiciones formales especificas, entonces la propiedad de tener una gramática que satisfaga una cierta condición abstracta podría llamarse un universal lingüístico formal, en caso de demostrarse que es propiedad de las lenguas naturales (46). La confusión "discurso/objeto" logra que los textos transformatorios reproduzcan imágenes circulares: puesto que las condiciones abstractas son reglas de las gramáticas, las reglas serán universales formales, y la gramática que las contiene tendrá un carácter universal. De este modo los universales formales se refieren al carácter de las reglas (i.e. la forma de las informaciones) que aparecen en las gramáticas y a sus posibles modos de interconexión (i.e. su actuación concreta en la gramática de las lenguas particulares), mientras que los universales sustantivos se ciñen a los rasgos fonológicos y semánticos (i.e. elementos 0 unidades contenidas en el interior de las propias reglas) que constituyen el vocabulario de la descripción del lenguaje (47).

En la segunda modalidad de los discursos transformatorios el tratamiento de los universales del lenguaje responde también a la misma concepción empirista del conocimiento. Lakoff (1966) formula la hipótesis de un autómata que pudiese generar las gramáticas de todas las lenguas naturales posibles. Este autómata será una teoría del lenguaje o una metateoría, sus reglas serán metarreglas o reglas universales y las gramáticas constituirán teorías de las lenguas particulares. En la tarea de construcción del autómata y de las gramáticas habrá que contar con un vocabulario, con cierto tipo de reglas y con una posible organización gramatical. La teoría lingüistica debe proporcionar un vocabulario universal cuyas unidades deben aparecer en todos los idiomas o en la mayoría de las lenguas posibles. Habrá unidades fonológicas del tipo de las descritas por Jakobson y ciertos símbolos categóricos o rasgos sintácticos. El autómata también definirá las formas de las reglas que se usen en la construcción de la gramática. Hasta esa fecha se contaba con varios tipos de reglas bien fundamentadas, como eran las reglas básicas -a las que luego renunciaron las gramáticas de la

(46) Cf. J.J. KATZ and P.M. POSTAL (1964, 29).

(47) Cf. N. CHOMSKY $(1965,29)$, J. LYONS $(1968,140)$ y J. LYONS $(1970,110-111)$. Dicen J.J. KATZ and P.M. POSTAL $(1964,160)$ que examples of substantive universals are: the phonological concepts of vocality, compactness, phoneme; the syntactic concepts of Noun Phrase, modifier, Q, wh; and the semantic concepts of (Male), (Physical Object), (Process), (Selector) [...] Examples of formal universals can be more or less detailed. An example of one of the most detailed formal universals is a specification that certain rules must be found in the syntactic component of any linguistic description - for example, the rule Rel $\rightarrow m d$. An example of one of the least detailed formal universals is the specification that some of the rules of a syntactic component be transformational in form". 
segunda modalidad-, y las reglas transformatorias, pero se tenian dificultades para definir otras reglas, y sobre todo para averiguar las restricciones que deberían imponérseles. Para proporcionar una organización de toda posible gramática el autómata necesitará fijar ciertos componentes de la gramática que incluyan el vocabulario, la forma de las reglas y la relación de estos componentes entre sí (48). El texto de Lakoff se caracteriza por el mismo eje "formal/sustancial» del universal perteneciente a los discursos de la primera modalidad. Las metateorias y sus metarreglas equivalen a las hipótesis de una gramática universal y de sus reglas universales, y se obtienen también mediante técnicas de extracción. Las unidades del vocabulario son los universales sustantivos y los tipos de reglas equivalen a los universales formales.

Tampoco otros textos logran escapar de la técnica de extracción con que se logra el universal en los discursos transformatorios. Fillmore (1967) defendia que "the view of universal grammar which is emerging is something like this: In their deep structure, the propositional nucleus of sentences in all languages consits of a $V$ and one or more NP's, each having a separate case relationship to the $P$ (and hence to the $V$ )" (49). $Y$ un año antes, refiriéndose al sistema de casos, decía Fillmore: "se supone que todos estos conceptos son universales sustantivos especificados por la teoría de la gramática" (50). Aunque la lógica expositiva de los sistemas de casos ha ido modificándose en Fillmore (1966, 1967, 1968a, 1968b, 1971), nunca se alteró, sin embargo, su propuesta inicial sobre los universales, pues las relaciones profundas de casos que constituye el centro de su teoria lingüística siguieron interpretándose como universales lingüísticos (51).

La misma problemática se puede encontrar en el breve pero sugestivo texto de McNeill (1970), para quien el lenguaje es una mezcla de universales débiles y fuertes. La causa necesaria y suficiente de los universales débiles son los universales de conocimiento y percepción. Los universales fuertes tienen una causa necesaria en el conocimiento o percepción, pero también necesitan de una habilidad puramente lin-

(48) Cf. G. LAKOFF (1966, 49-51).

(49) Cf. CH. J. FILLMORE $(1967,51) . V=$ Verbo, NP's = Sintagmas nominales y $P=$ Proposición.

(50) Ct. CH. J. FILLMORE (1966, 51-52).

(51) J.M. ANDERSON (1970, 14 ss.), destacó el carácter universal que tenían las relaciones subyacentes de casos: "I assume that the underlying case relations are a universal of language; further, that they are introduced within a set of (al least partially) universal 'base structures'. That is (despite Chomsky, 1968:57), I concur with Bach's (1967, 14) arguments for adopting initially the 'universalist-unitarian' hypothesis concerning the nature of the base". 
güística. Por ejemplo, las categorias gramaticales nombre y verbo aparecen en la estructura universal subyacente del lenguaje no sólo porque sin ellas serían imposibles las descripciones lingüísticas sino también porque la teoría innata sobre la adquisición del lenguaje supone que los niños organizan espontáneamente las oraciones mediante tales categorias. En la constitución de los universales lingüísticos fuertes intervienen las categorias cognoscitivas propias de los universales débiles, esto es, las categorías actor, acción y percepción, pero también necesitan una habilidad lingüística (52). Aunque en ningún momento McNeill aclara qué significa este último concepto, es fácil averiguar que la habilidad lingüística es una razón psicológica para diferenciar ambos tipos de universales. Los universales fuertes de McNeill son una mezcla de los universales formales y sustantivos de Chomsky, Katz y Postal, y su esencia consiste en asumir un contenido «formal/sustancial»-cuyo desvio se asegura mediante el universal errático, que tiene dos causas suficientes - del que cada lengua extrae en el espacio del objeto las categorías necesitadas por los niños para dar forma a la abstracción oracional, y en el espacio del discurso las categorias precisas para que los lingüistas puedan describir las lenguas. Los universales débiles aspiran a ser categorías explicativas del pensamiento sin lenguaje, en el que se pretende conseguir el mayor nivel posible de abstracción y de pureza del conocimiento (53).

Los discursos transformatorios encuadrados en cualquiera de sus dos modalidades contienen una concepción empirista del conocimiento caracterizada por un triple proceso de extracción, abstracción y aplicación que es particularmente visible en la delimitación entre universales formales y sustantivos. Un universal formal importante lo constituye el principio de que las transformaciones se rigen por un mecanismo ciclico, el cual exige que aquéllas se apliquen siguiendo un orden fijo. El proyecto del ciclo transformatorio está ya configurado en 1965, pero se completa en los textos de la segunda modalidad con la

(52) Cf. D. MCNEILL (1970, 534-535).

(53) La situación no suele alterarse en otros discursos transformatorios. Según E.H. Bendix $(1970,394)$ la descripción de lenguas diferentes no sólo exigiria un conjunto universal de rasgos fónicos, de los que cada lengua pudiese extraer los que necesitara sino también unos rasgos metalingüisticos significativos. "The cross-linguistic validity of such semantic elements is based on the prima facie intertranslatability of languages to a significant degree. Their validity as part of a larger semantic metatheory would be supported by the ability to account for the observable evidence of bilingual's responses with respect to cross-linguistic similarities and differences". Estos elementos universales se combinarian de diferente manera en las definiciones de los artículos léxicos de lenguas distintas, y también se complementarian mediante componentes especificos en cada lengua. 
simplificación del mecanismo reglado de las gramáticas y con la utilización de las transformaciones como elemento técnico básico con el que opera el sistema. Chomsky (1965) defiende que la gramática contiene una secuencia lineal de transformaciones singulares que se aplican a los diagramas generalizados cíclicamente, según un principio aplicativo de ordenación extrínseca que es radicalmente distinto al orden interno constitutivo de las reglas básicas. En primer lugar, la sucesión $T_{1}, \ldots, T_{\mathrm{m}}$ "se aplica a una configuración dominada por $O$ (es decir, a una configuración [o ...] o) y que no contenga ningún otro caso de $O$. Cuando las reglas de transformación se han aplicado a todas las configuraciones de estas características, pasan inmediatamente a aplicarse a una configuración dominada por $O$ y que sólo contenga configuraciones dominadas por $O$ a las cuales ya se hayan aplicado las reglas. Se sigue con este proceso hasta que las reglas se aplican al indicador sintagmático completo dominado por la $O$ inicial del indicador sintagmático básico. Llegado este punto, nos encontramos con una estructura superficial» (54). En cuanto a su fundamentación teórica, el ciclo transformatorio se apoya en la capacidad innata y en el mecanismo de adquisición lingüística que poseen los hablantes de una lengua natural. Chomsky afirma que este principio cíclico uforma parte sin más del dispositivo innato que la persona utiliza para interpretar el limitado y fragmentario conjunto de datos de que dispone" (55). Al contrario que el empirismo estricto, el discurso transformatorio no puede imaginar que el hablante que aprende una lengua pueda derivar el ciclo mediante procedimientos inductivos a partir de los datos primarios. El ciclo es un principio innato pero no asociativo, y es un principio organizador que determina el carácter de la exposición lingüística y la construcción de la gramática que constituye el conocimiento adquirido de una lengua. La fundamentación del ciclo mediante las categorías innatismo, proceso de adquisición lingüística y aprendizaje de la gramática revela que no se trata de un simple dispositivo técnico del discurso transformatorio sino que descubre un proceso epistemológico usual en el pensamiento clásico, consistente en construir un objeto imaginario de discurso destinado a identificarse y a reflejarse en el objeto real, al que de este modo cree conocer. La técnica utilizada es hipotética, y como tal atravesada por simples suposiciones. Se supone que toda forma de la gramática universal es innata, que la gramática transformatoria es la única forma de esta gramática universal, que el ciclo es, por consiguiente, una técnica innata y no inductiva, desti-

(54) Cf. N. CHOMSKY (1967a, 309-310) y N. CHOMSKY (1965, 124-128 ss.).

(55) Cf. N. CHOMSKY (1967a, 328). 
nado a ordenar todas las reglas y transformaciones gramaticales. EI ciclo determina la estructura real de las lenguas reales, ya que la gramática es un reflejo discursivo de la realidad del lenguaje general o de las lenguas particulares. Es así como el principio cíclico innato se convierte en una técnica aplicable a las estructuras reales de las lenguas y constituye un universal formal básico tanto en la primera como en la segunda modalidad de los textos transformatorios.

Lakoff definió el ciclo transformatorio con los mismos términos que Chomsky: "las reglas se aplican primero a la oración más profundamente incrustada, luego a la situada inmediatamente por encima de ella, y así sucesivamente hasta que se hayan tratado todas las oraciones que se encuentren en la estructura profunda de la oración compleja del caso" (56). Cabe la posibilidad de que ciertas reglas se apliquen a la totalidad del indicador sintagmático profundo. antes de comenzar la aplicación de regla cíclica alguna, y del mismo modo también es posible que otras reglas se apliquen después de haberlo hecho todas las reglas ciclicas. En caso de contar con ambas posibilidades lógicas, la organización del componente transformatorio se dividiría en preciclo, ciclo y posciclo (57). Por otra parte, Chomsky -en notas de clase ofrecidas en el M.I.T. durante 1966, según recuerda Lakoff-, sugirió la posibilidad de que existieran reglas último-cíclicas, intercaladas entre las cíclicas y ordenadas antes que ellas, pero aplicables sólo en el último ciclo. Lakoff defendió que las construcciones relativas no restrictivas y la formación apositiva no podían derivarse precíclicamente porque en las coordinadas copulativas los dos miembros coordinados habian de ser compatibles; ni podían derivarse cíclicamente pues habían de hacerlo de oraciones coordinadas en el nudo superior $O$, ni tampoco podían derivarse poscíclicamente ya que las reglas ciclicas pronominales han de aplicarse después de la formación de construcciones relativas no restrictivas. Lakoff elige el término último-cíclico de Chomsky y rechaza el poscicio. Las cláusulas relativas no restrictivas asi como las construcciones apositivas han de derivarse en el último ciclo pero antes de cualquier regla cíclica. De este modo, las reglas preciclicas, cíclicas y último-cíclicas incorporan a la teoría gramatical "unos universales enormemente abstractos de la forma lingüistica" (58). El ciclo transformatorio, compuesto de preciclo, ciclo y posciclo o último-ciclo, es un universal formal que el discurso aplica al objeto una vez que ha extraído de antemano la naturaleza abstracta de éste. Pero

(56) Cf. G. LAKOFF (1966, 86 ss.).

(57) Cf. G. LAKOFF $(1966,95)$.

(58) Cf. G. LAKOFF $(1966,96$ y 101-109). 
la aplicación de un proceso de extracción y abstracción universales no es autónoma, y se supedita a la necesidad interna del sistema, hasta el punto de que puede desbordar los propios limites en que se encuadra.

Si se entiende la epistemología del desbordamiento de sus límites - que no es más que la técnica del cambio de montaje-, se puede comprender con exactitud la mutación del ciclo. McCawley (1969a) (59), como antes habian propuesto Lakoff y Ross, sugirió que el componente transformatorio de una gramática deberia dividirse en tres subsistemas de reglas: las transformaciones precíclicas, cíclicas y poscíclicas. Pero McCawley truncó el deseo de ampliar la teoría de la gramática para incluir reglas precíclicas, deseo manifestado por Lakoff (60) a raíz de la existencia empírica de la transformación pronominal de it en inglés: «l will ignore pre-cyclic transformations, since the one known pre-cyclic transformation (namely the sentence pronominalization which gives rise to the it of such sentences as Margaret is believed by many to be pregnant, but she denies it) is irrelevant to my argument" (61). El ciclo transformatorio se redujo en McCawley (1968b, 1969a, 1969b y 1970) al ciclo y al posciclo: "the transformations of a language divide into two subsystems, a cycle and a system of postcyclic rules" (62). Las inserciones léxicas ordenadas entre el ciclo y el posciclo se comportarian de manera similar en todas las lenguas - si call lexical insertions to take place after the cycle but before the postcyclic rules would be another way of constraining lexical insertions so that their ordering would not be a way in which languages could differ" (63)-, y ambos sistemas desempeñarian un papel destacado como universales formales. McCawley (1969a) recuerda que el ciclo y el posciclo fueron propuestos como partes de la sintaxis para relacionar las estructuras profundas - que eran objetos sintácticos, pero no semánti$\cos -$, con las estructuras superficiales en una época en la que los lingüis-

(59) Se trata de un discurso poco divulgado por el empirismo de la literatura transformatoria, pero que es desde su mismo título El inglés como lengua vSO una auténtica revelación de intenciones, pues McCawley (1969a, 211-228) pretende demostrar que el orden "sujeto/verbo/objeto" es el resultado de una transformación sobre un orden profundo en el que las cláusulas comienzan por predicados, esto es, por una representación semántica en la que las categorias nombre, verbo, adjetivo, conjunción, etc., figuran como elementos indiferenciados. El texto de McCawley contiene el deseo implícito de que el orden VSO asignado al inglés sea la disposición de los constituyentes profundos de todas las lenguas. Todos los universales tipológicos de Greenberg bien pudieran ser variantes de VSO.

(60) Cf. G. LAKOFF (1966, 96-98).

(61) Cf. J.D. MCCAWLEY (1969a, 211).

(62) C.. J.D. MCCAWLEY (1968b, 163).

(63) Cf. J.D. MCCAWLEY (1968b, 163). 
tas creian en la distinción "sintaxis/semántica». Pero posteriormente algunos lingüistas, incluido el propio McCawley, han rechazado la distinción «sintaxis/semántica" y han tratado las transformaciones como mecanismos para asociar las representaciones semánticas con sus correspondientes estructuras de superficie, sin recurrir a ningún nivel de estructura profunda que fuese distinto al de la propia representación semántica. Pues bien, incluso desde esta nueva lectura semántica del sistema, el ciclo y el posciclo permanecen inalterables como universales formales (64).

¿Cómo fue la tentativa histórica por formular una concepción del ciclo como universal formal en los discursos de la segunda modalidad? McCawley (1969b) puso de manifiesto que hay razones suficientes para creer que todas las transformaciones cíclicas son transformaciones preléxicas, y de entre ellas destacaba "the existence of lexical items whose meanings appear to be paraphraseable only in terms of the outputs of these transformations, eg. reflexivization (suicide $=$ «killing oneself»), passivization (under surveilance $=$ «being watched»), and Equi-NP-Deletion (malinger $=$ "pretend to be sick»)» (65). Las transformaciones preléxicas no sólo incluyen transformaciones que combinen material semántico con posibles artículos léxicos sino también transformaciones ordinarias, tales como la transformación de supresión de sintagma nominal equivalente o de inserción de there en inglés. Por ejemplo, 'excusarse' se somete a la transformación de supresión de sintagma nominal equivalente en determinadas condiciones de identidad entre sus sujetos:

(1) a. Tomás se excusó ante Susana por besar a Lucia

b. $X$ se excusa ante $Y$ por $S=R E Q U E R I R(X, Y, P E R D O N A R(Y, X, S)$.

En (1a) el sujeto de 'besar' es 'Tomás' y no 'Susana'. Si 'excusarse'

(64) Cf. J.D. MCCAWLEY (1969a, 215): «In particular, the notions of cycle and postcyclic transformation carry over unchanged to the newer concept of grammarn. Cf. J.D. MCCAWLEY (1969b, 253-254): "The conception of transformation and of the way in which transformations interact (e.g. the conclusion that there is a cycle of transformations which is followed by a system of post-cyclic transformations, the transformations of each of these two systems being ordered) is the same as in recent versions of transformational grammar wich a level of deep structure. Cf. J.D. MCCAWLEY (1970, 293): "A demonstration that not all transformations of English belong to a cycle is given in Ross (1967a) and is reported in slightly revised form in McCawley (1969a). The conception of a grammar which Ross arrived at (and which 1 assume here) is that the transformations form two systems: a cycle, whose rules interact in the manner just described, and a system of post-cyclic transformations, which interact in a somewhat simpler manner: they have a fixed order, and all applications of each of them precede all applications of the next one".

(65) C. J.D. MCCAWLEY (1969b, 254). 
tiene la estructura semántica (1b) propuesta por Fillmore (66), entonces el sujeto de la $S$ inferior, al identificarse con el objeto indirecto de 'perdonar', se elimina. Este objeto indirecto es idéntico al sujeto de 'requerir' y al sujeto de 'excusarse', con lo que se produce una supresión del sintagma nominal.

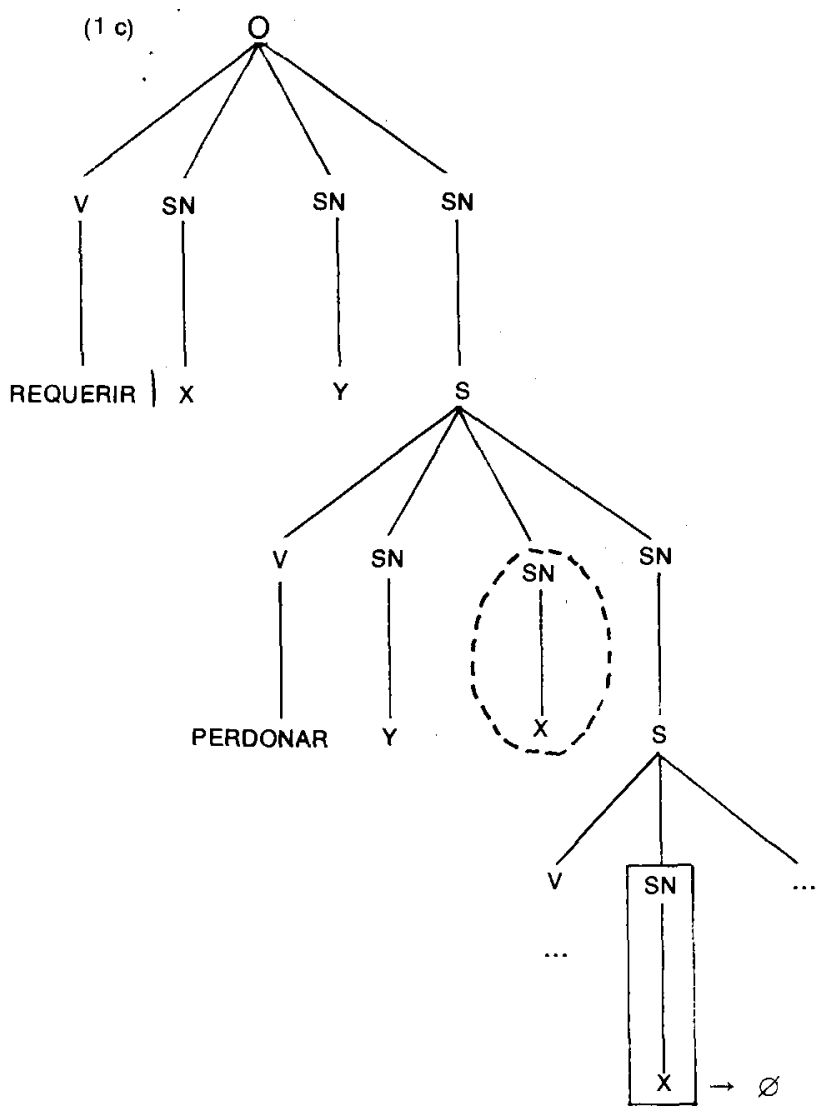

(66) Cf. J.D. McCAWLEY (1971, 347). CH. J. FILLMORE $(1969,289)$ propuso la siguiente descripción semántica para los verbos de juicio apologize y forgive:

APOLOGIZE (Defendant, Affected(to), Situation (for) (Performative)

Meaning: SAY (Defendant, " $X m$, Addressee)

$X \quad=$ REQUEST (Defendant, FORGIVE) VICTIM, DEFENDANT,

Situation) 
De una importancia excepcional para la constitución del ciclo son las transformaciones preléxicas de elevación. A fin de refutar la hipótesis de Chomsky, según la cual existe una diferencia de naturaleza formal entre las representaciones semánticas y sintáctica que confluirían en el nivel de estructura profunda, McCawley (1968a) afirma que no hay diferencia "sintaxis/semántica» y que las representaciones semánticas son objetos formales de la misma naturaleza que los diagramas que rotulan la estructura sintáctica. Estas aseveraciones de McCawley confirman la existencia de una transformación de elevación del predicado y descansan en el reducido número de categorías sintácticas básicas que existen en la estructura profunda (67). Ross (1966c) -artículo que es representativo de esta técnica de reducción categórica-, no necesita recurrir a la diferencia establecida por Chomsky (1965) entre el sintagma predicativo, el auxiliar y el modal porque los auxiliares ponen en funcionamiento una transformación de elevación del predicado que desliga el sintagma verbal de la oración incrustada y lo coloca después del verbo:

\author{
Presupposition: BAD (Situation) \\ Presupposition: RESPONSIBLE (Defendant, Situation) \\ Presupposition: ACTUAL (Situation) \\ FORGIVE (Affected, Defendant, Situation (for) (Performative) \\ Meaning: DECIDE (Affected, “ $X$ ") \\ $X=$ ? (Affected will not hold Situation against \\ Defendant) \\ Presupposition: BAD (Situation) \\ Presupposition: RESPONSIBLE (Defendant, Situation) \\ Presupposition: ACTUAL (Situation)
}

También G. LAKOFF (1966, 127-132) defendió que la supresión de sintagma nominal equivalente sólo puede aplicarse después de reglas cíclicas, pero sin llegar a ser último-cíclica ni, por supuesto, precíclica. Cf. J. ROSS (1966b, 354) y B. HALL-PARTEE (1973, 16 ss.), quien estudia la relación entre la transformación pronominal y la Super-Equi-NP Deletion.

(67) Esta técnica epistemológica de reducción categórica la analizo en M. CRESPILLO (1982). 


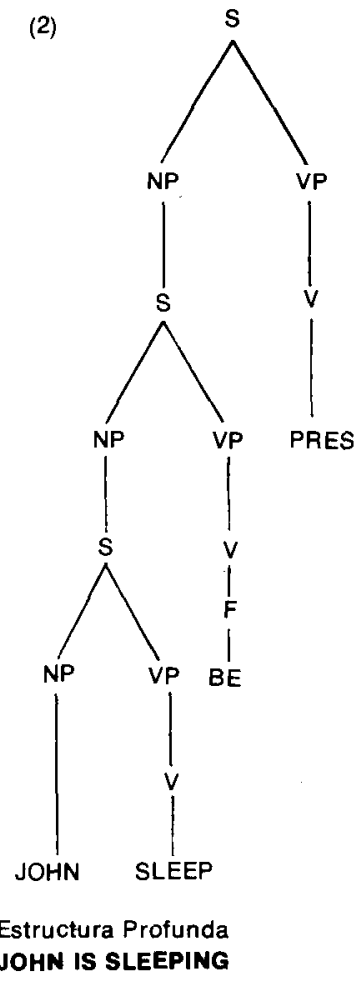

(3)

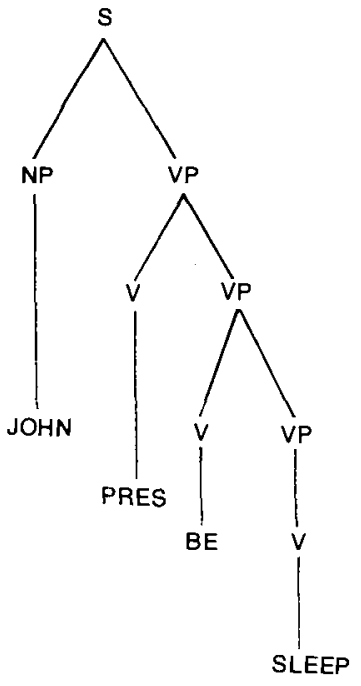

Resultado de la T de elevación del Predicado

Los auxiliares tienen la peculiaridad adicional de combinarse con el constituyente tiempo mediante una transformación bastante temprana, y el conjunto de la oración está afectado por varias transformaciones que operan sobre el verbo del constituyente más amplio. En el ejemplo anterior la transformación de elevación del predicado sufre dos procesos. En primer lugar, la transformación afecta al verbo del símbolo superior 'PRES' y lo combina con el verbo de la oración menos incrustada, el cual se coloca detrás. En segundo lugar, la transformación atañe al verbo menos incrustado 'BE' y lo combina con el verbo de la oración más incrustada 'SLEEP', el cual se coloca detrás (68). En McCawley (1968b) la transformación preléxica de elevación del predicado

(68) Cf. J.D. McCAWLEY (1968a, 137-138). 
interviene en la transformación de inserción léxica, la cual no se sitúa sobre la última representación semántica sino sobre las estructuras derivadas obtenidas tras las transformaciones preléxicas. Los elementos semánticos de

(4) $X$ mató a $Y$ : $X$ causó que $Y$ se convirtiera en 'no vivo' no se agrupan de la misma manera en la representación semántica que en las piezas léxicas, ya que antes de insertar 'matar' es preciso que 'causar', 'convertirse', 'no' y 'vivo' se agrupen en una unidad. Entonces tiene lugar la transformación de elevación del predicado que adjunta un predicado al inmediatamente superior (69). El proceso a seguir sería el siguiente:

(5)

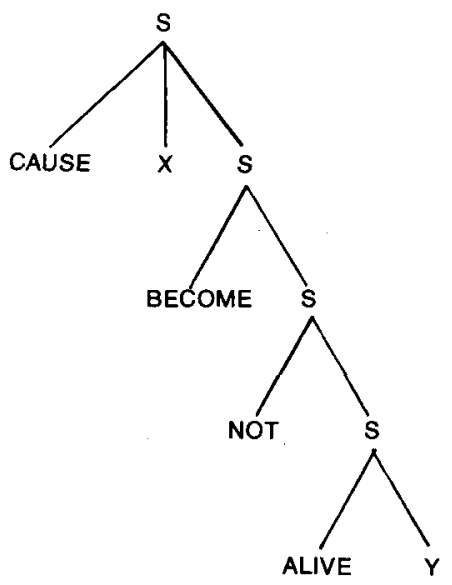

(69) En otro de sus artículos McCawley puso de manifiesto que la regla de elevación del predicado cumple la misma función que la transformación de adjunción en sintaxis. Cf. J.D. McCAWLEY (1971, 345): La transformación de «Predicate-raising does exactly the same kind of thing as do the adjunction transformations of syntactic studies that assume a distinction between syntax and semantics, only it does it to a structure whose ultimate elements (or at least, some of them) are not morphemes but semantic units". El hallazgo de un sistema de transformaciones que produzca combinaciones de material semántico y que se puedan convertir en los "posibles articulos léxicos del inglés", es, según McCawley, un "programa de investigación" del que sollo fragmentos de él se han llevado a cabo hasta ahora. 
(6)

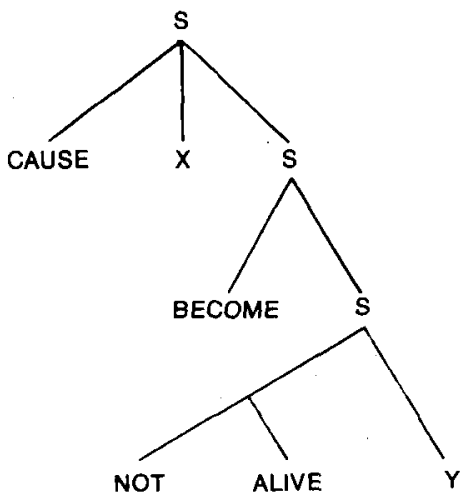

(7)

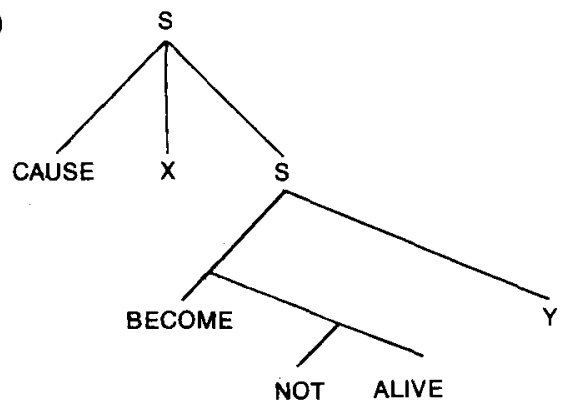

(8)

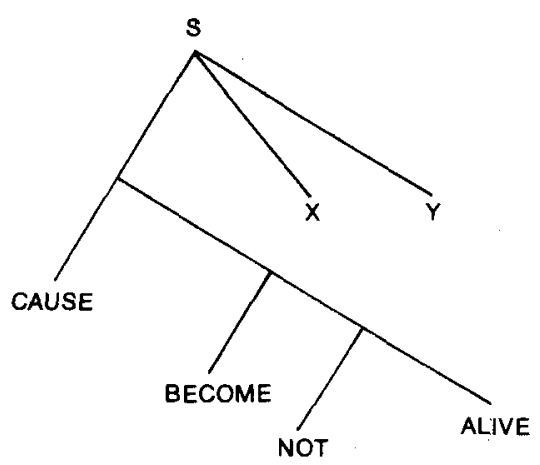


Si la transformación de inserción léxica se aplica tras la transformación de elevación del predicado, el artículo de diccionario correspondiente a 'matar' se logra mediante una transformación que sustituye el subdiagrama izquierdo de la figura (8), esto es, 'causar convertirse en no vivo' por 'matar':

(9)

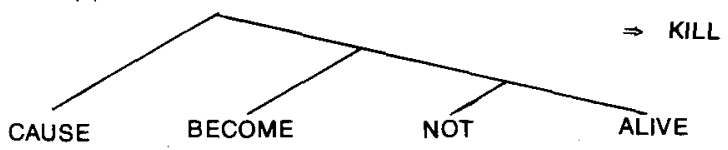

La transformación de elevación del predicado es una transformación optativa, ya que no es necesario llevar a cabo todos los estadios de la última derivación. Por ejemplo, si no se realiza el último proceso de la transformación se obtendría John caused Harry to die. Pero además esta transformación produce muchas configuraciones que no corresponden a ningún artículo de diccionario: mientras que la figura (10) no contiene una estructura semántica anómala, en cambio el marcador (11) carece de pieza léxica correspondiente. El subdiagrama de la figura (11) tendría que ser rechazado:

(10)
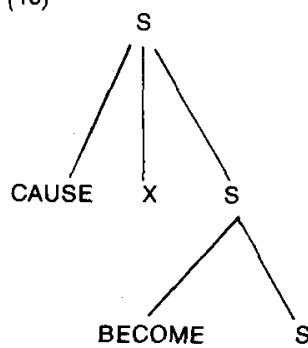

(11)

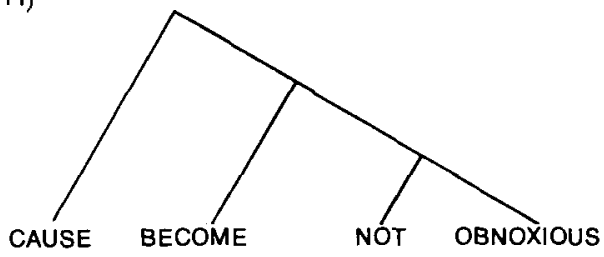

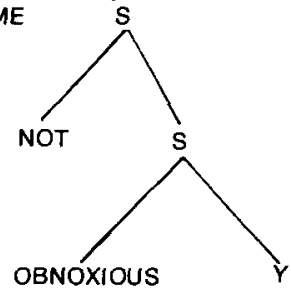


La transformación de elevación del predicado contiene las transformaciones causativas e incoativas de Lakoff (1965), y permite que McCawley imponga a las gramáticas una constricción universal sobre las estructuras superficiales: "a surface structure is well-formed only if all its terminal nodes bear lexical items" (70).

El ciclo no sólo debe estar dispuesto como un conjunto de transformaciones preléxicas sino que también debe contener un principio de orden para sus transformaciones. Tras observar los problemas que surgen con las partículas completivas cuando se aplican a la totalidad de las estructuras las transformaciones de sustitución de $i t$ y pasiva, Lakoff (1966) aseguró que todas las dificultades se resolverían si se aplicaran dichas transformaciones de manera ordenada y sucesiva en el ciclo (71). Del mismo modo, la transformación reflexiva ha de aplicarse cíclicamente, antes o después de la transformación de sustitución de $i t$. También McCawley (1970) observó que la transformación de elevación debe aplicarse antes que la reflexiva para obtener (12), mientras que el proceso se invierte en la derivación de (13).

(12) Max ${ }_{i}$ believes himself $f_{i}$ to be a werewolf

(13) Agnes believes John $n_{\mathrm{i}}$ to have shot himself

Por consiguiente, tienen que existir restricciones sobre el orden en que deben aplicarse las transformaciones. Cuando una transformación ocupa el primer lugar en ciertas derivaciones y otra lo ocupa en derivaciones diferentes - como es el caso de las transformaciones reflexivas o de elevación-, ambas derivaciones difieren en cuanto a las alturas relativas de las cláusulas a las que afectan, y la aplicación de una de las transformaciones a una cláusula inferior se toma como precedente de

(70) Cf. J.D. McCAWLEY (1968b, 157-159) y J.D. McCAWLEY (1969b, 251-253). La transformación de elevación del adverbio prepuesto y pospuesto como regla preléxica anterior a la elevación del predicado se estudia en J.D. McCAWLEY (1971, 348-350). Para la transformación preléxica de elevación del sujeto y el consiguiente reemplazo del pronombre, $C f$. P.M. POSTAL (1972) donde se analizan las diferentes propuestas de G. Lakoff, J. Ross, P.S. Rosenbaum, J.D. McCawley, P.M. Postal y la contrapropuesta de N. Chomsky. El carácter cíclico de la regla de elevación se analiza en P. M. POSTAL $(1972,267-268)$ y en J. D. McCAWLEY $(1971,354)$. En español, una aplicación de la elevación de nudo en las subordinadas sustantivas se realiza en V. DEMONTE $(1977,86)$. Según P. KIPARSKY y C. KIPARSKY (1967, 57-59) la constricción del sintagma nominal complejo explica por qué la transformación de elevación del sujeto nunca tiene lugar en las completivas factitivas. Otras reglas preléxicas, como la pasiva o la transformación que cambia el instrumento con el verbo (MeansIncorporation T) se estudia en J.D. McCAWLEY (1971, 351-355). La reducción generalizada de la conjunción como mecanismo preléxico se desarrolla en J.D. McCAWLEY (1969b, 254).

(71) C.F. G. LAKOFF $(1966,69-74$ y 82-93). 
la aplicación de la otra a una superior. En la derivación de (13) la transformación reflexiva afecta a la cláusula subordinada y se aplica antes que la transformación de elevación que afecta a la cláusula principal. En casos como (12), donde ambas transformaciones afectan a la misma cláusula, la aplicación contiene un orden fijo, ya que primero opera la transformación de elevación y después la transformación reflexiva (72).

Ross (1967) defendió que sólo pueden explicarse determinados hechos sobre los pronombres anafóricos si las reglas que los introducen son transformaciones obligatorias ordenadas cíclicamente. Desde el supuesto de que la transformación pronominal necesita una identidad de referentes - concepción que sufriría más tarde cambios relevantes en la gramática transformatoria-, Ross propone que dicha transformación se mueve en dos direcciones: la transformación pronominal hacia adelante (forward pronominalization) que cambia a (14) en (15), y la transformación pronominal hacia atrás (backward pronominalization) que convierte a (14) en (16).

(14) Después de que John Adams, se despertara, John Adams $s_{\mathrm{i}}$ tenia hambre.

(15) Después de que John Adams ${ }_{\mathrm{i}}$ se despertara, él tenia hambre.

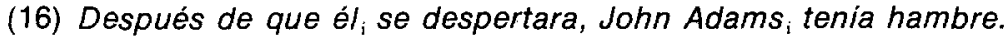

Algunas construcciones sólo admiten una dirección determinada: (17) sólo conoce la transformación pronominal hacia adelante.

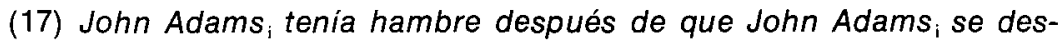
pertara.

(18) John Adams, tenia hambre después de que él ${ }_{\mathrm{i}}$ se despertara.

(19) * $E l_{\mathrm{i}}$ tenía hambre después de que John Adams, se despertara.

La diferencia entre (14) que admite las dos direcciones y (17) que sólo acepta una de ellas se explica por una regla cíclica pronominal, ordenada después de un adverbio prepuesto, que pueda aplicarse o no (73). La regla pronominal no puede preceder a las restantes reglas transfor-

(72) Cf. G. LAKOFF (1966, 93-95), R.A. JACOBS and P.S. ROSENBAUM (1968, 184-192) y J.D. MCCAWLEY (1970, 292).

(73) Cf. J.R. ROSS (1967, 188-190). Según D.T. LANGENDOEN (1969, 79-80): „We may say that a pronoun substitutes for an NP under one of two conditions: (1) optionally in case the NP is correferential with an NP following it in a sentence and the first NP is in a clause subordinate to the sentence containing the second NP [...]. The other condition is: (2) obligatorily in case the NP is coreferential with and NP preceding it in a sentence in which both occur, and optionally in case the NP preceding it is in a previous sentence of the discurse". La primera condición la llama Langendoen backwards pronominalization, y la segunda forwards pronominalization. 
matorias porque depende de las transformaciones de adverbio prepuesto y pasiva. Si la pasiva es una regla cíclica, la transformación pronominal tendrá que ser también cíclica o poscíclica, pero nunca precíclica. Pero sobre la base de ejemplos como (20) cabe suponer que si la regla pronominal fuese poscíclica tendrían que imponerse condiciones complejas sobre la transformación pronominal hacia adelante para que no se produjeran oraciones agramaticales como $(20 \mathrm{~b})$. Y aún cuando tales condiciones se formularan y añadieran a la gramática, la condición (iii) de (21) tendría que enunciarse de manera que impidiera la generación de $(22 b)$.

(20) a. Realizing that Oscar ${ }_{\mathrm{i}}$ was unpopular didn't disturb Oscar $_{\mathrm{i}}$

b. *Realizing that Oscar ${ }_{\mathrm{i}}$ was unpopular didn't disturb him ${ }_{\mathrm{i}}$

c. Realizing that he ${ }_{i}$ was unpopular didn't disturb Oscar ${ }_{i}$

(21) Transformación pronominal

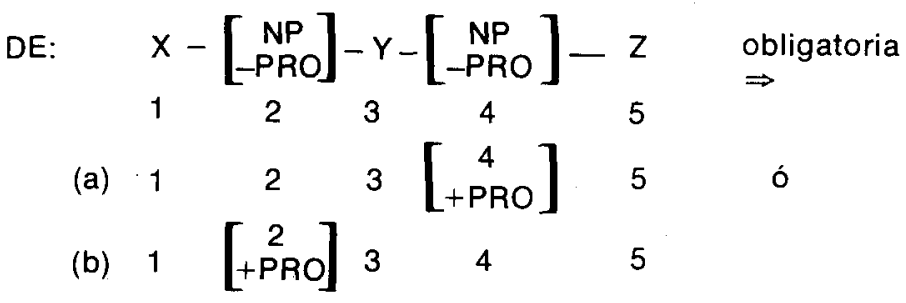

Condiciones:

(i) $2=4$

(ii) La transformación pronominal hacia adelante no está sujeta a condiciones.

(iii) La transformación pronominal hacia atrás sólo se permite si el sintagma nominal 2 de la descripción estructural está dominado por una oración subordinada que no contiene el sintagma nominal 4.

(22) a. Oscar ${ }_{\mathrm{i}}$ realized that he $\mathrm{i}_{\mathrm{i}}$ was unpopular.

b. " ${ }^{*} e_{i}$ realized that Oscar ${ }_{i}$ was unpopular.

Si la transformación pronominal se formula únicamente como regla cíclica, obligatoria en la mayoria de los contextos, pueden evitarse condiciones innecesarias que se requeririan en el caso de considerarse como regla preciclica o poscíclica (74).

En contra de la tesis de Ross, Lakoff defendió que la transformación pronominal tenía que ser último-cíclica y seguir a todas las reglas reordenadas de un ciclo. El mismo planteamiento sostuvo Postal (1970).

(74) Cf. J.R. ROSS $(1967,190-200)$. 
Por el contrario, Jackendoff desarrolló la tesis de Ross y propuso que la transformación pronominal ha de fijarse al final del ciclo transformatorio porque aumentan sus posibilidades de realización cuando va precedida de interrogación y disminuyen cuando interviene la extraposición (75). Si se acepta que las transformaciones pronominal y reflexiva han de ser cíclicas, ¿cuál sería el orden que cabría establecer entre ambas? (76). Jackendoff recuerda que los contextos en que se producen ambas reglas son muy similares, por lo que "it would be an important result if they could be ordered together and hence partially collapsed" (77). En cambio, Postal (1971) sostuvo que tales transformaciones deben guardar un orden distinto no sólo porque la regla reflexiva es cíclica mientras que la pronominal es último-cíclica, sino también porque la interrogativa prepuesta interviene entre las dos reglas. El primer argumento de Postal fue bastante efímero, ya que este mismo lingüista situó la transformación pronominal como última regla del ciclo transformatorio, con igual derecho que la reflexiva a participar de un carácter cíclico. Pero el segundo argumento de Postal entró en conflicto con la Rule of Tree-Pruning que habia formulado Ross. Según Ross hay una convención general que suprime el constituyente $S$ cuando éste domina a un sintagma nominal o a un sintagma verbal. La aplicación de la interrogación prepuesta sobre el ciclo $S^{1}$ provoca el recorte del nudo $S^{2}$ en (23) - que es la estructura profunda de Who did you see stab you-, puesto que sólo domina a un sintagma verbal. El diagrama (24) sería su estructura derivada.

(75) Cf. R. S. JACKENDOFF (1972, 121-123).

(76) Estudios clásicos sobre la transformación pronominal en inglés así como sobre la regla reflexiva en cuanto transformación singular son respectivamente los de R. B. LEES and E. KLIMA (1963, 145-159) y N. CHOMSKY (1958, 232-233). Cf. también J.J. KATZ (1966, 114). El análisis de D. T. LANGENDOEN $(1969,81-88)$ tampoco incorpora ninguna novedad. Otro problema empirico importante en el orden del ciclo transformatorio son las proformas. Cf. B. LILES (1971, 83-91). Una interpretación sobre los verbos reflexivos españoles se lleva a cabo en S.S. BABCOCK (1970). La transformación pronominal del it factitivo y expletivo la estudian P. KIPARSKY and C. KIPARSKY $(1967,65-68)$, y la transformación pronominal y la cadena de mandatos R.W. LANGACKER (1966, 160-186).

(77) Cf. R.S. JACKENDOFF $(1972,143)$. 

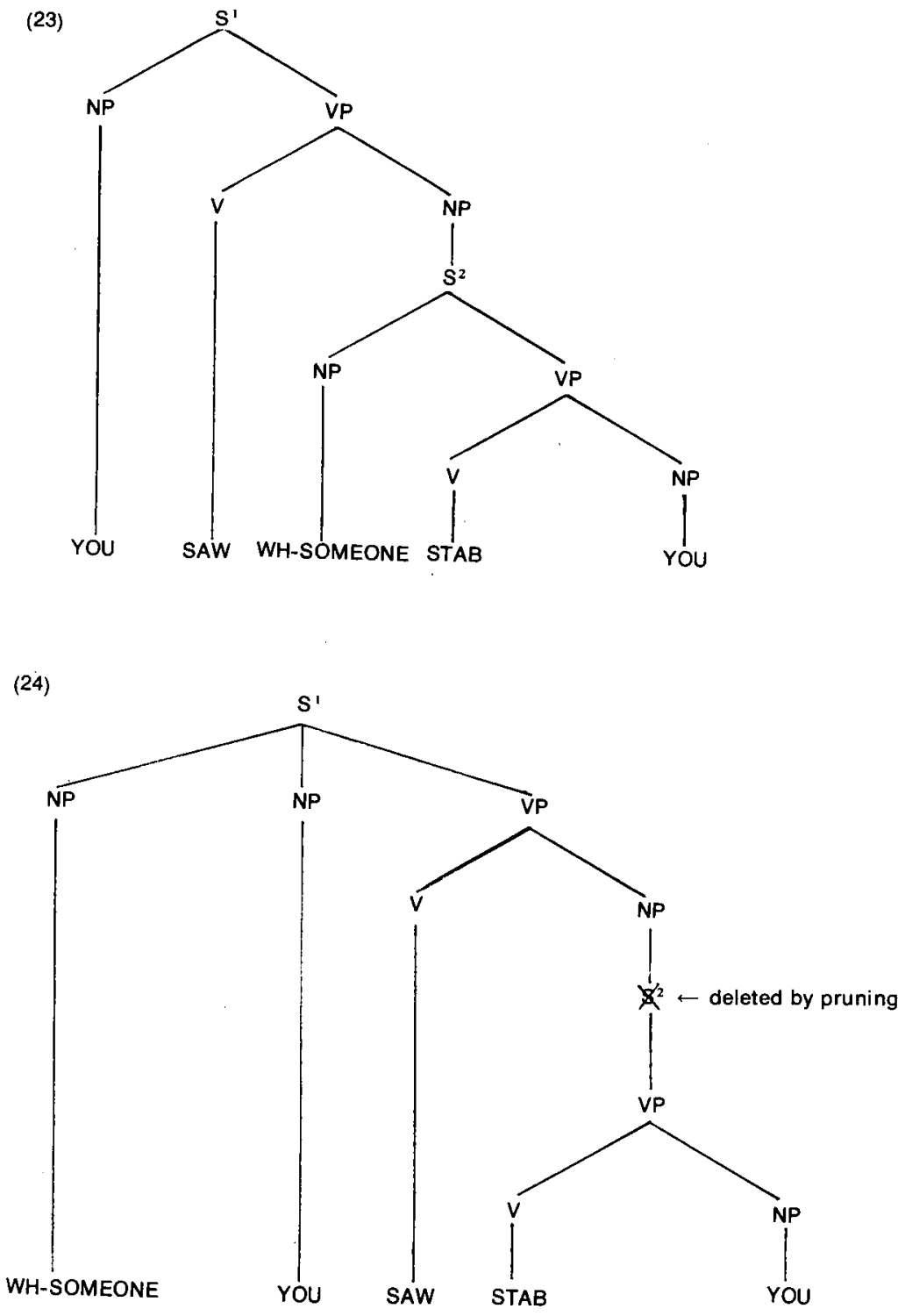
Si la transformación reflexiva tiene lugar después de la formación de (24), su estructura superficial sería (25) en lugar de (26), ya que los dos pronombres you se encuentran en la misma oración simplificada:

(25) "Who did you see stab yourself?

(26) Who did you see stab you?

Por tanto, Postal concluye que la regla reflexiva debe tener lugar antes de que el constituyente $S^{2}$ sea recortado mediante la aplicación de la interrogación prepuesta. Las transformaciones reflexiva y pronominal no pueden fundirse porque esta última se ordena tras la interrogación prepuesta. Pero en la teoría interpretativa de Jackendoff el problema de Postal deja de existir: "on the $S^{2}$ cycle, reflexivization will apply, making the entry Wh-someone coref you. Then, in the $S^{1}$ cycle, even if the node $S^{2}$ has been pruned, the you from $S^{2}$ violates condition(a) of reflexivization, since it already appears in the table. Thus it can undergo normal pronominalization and be marked coreferential with the other you, even though they are now in the same simplex sentence. On the other hand, if yourself is substituted for you in $S^{2}$, it is (anomalously) marked coreferential with Wh-someone on the $S^{2}$ cycle, so $(25)$ is predicted to be unacceptable" (78). De este modo, incluso con el recorte del nudo $\mathrm{S}^{2}$, la teoría interpretativa sobre la transformación reflexiva produce una significante generalización, ya que permite que dicha transformación se ordene después de una interrogación prepuesta y que se funda con la transformación pronominal (79).

El posciclo no ha sido tan comentado como el ciclo en la teoria transformatoria. Rosenbaum denominó transformación de extraposición a una operación que mueve opcionalmente una oración incrustada hasta el final de su cláusula principal. Ciertos textos transformatorios asignan esta transformación al ciclo, mientras que otros la sitúan en el posciclo. (27) y (28) ilustran esta transformación:

(27) The claim that the world was round was made by Columbus.

(28) The claim was made by Columbus that the world was round.

Rosenbaum afirma que "when a noun phrase complement follows its 'head' noun (e.g. 'claim'), this transformation detaches the embedded sentence from under the domination of the noun phrase of which it is a complement and moves it to the end of the main sentence. When the

(78) Cf. R.S. JACKENDOFF (1972, 143-145).

(79) Cf. J.D. MCCAWLEY (1969a, 212-213). M." L. RIVERO (1977, 19-35) ha caracterizado también como cíclica la elevación de la negación. Empíricamente, esta transformación tropieza con dificultades, ya que se bloquea en les cláusulas factitivas. Cf. P. KIPARSKY and C. KIPARSKY $(1967,59-60)$. 
extraposition transformation is applied to the structures (29), it generates (30)" (80).

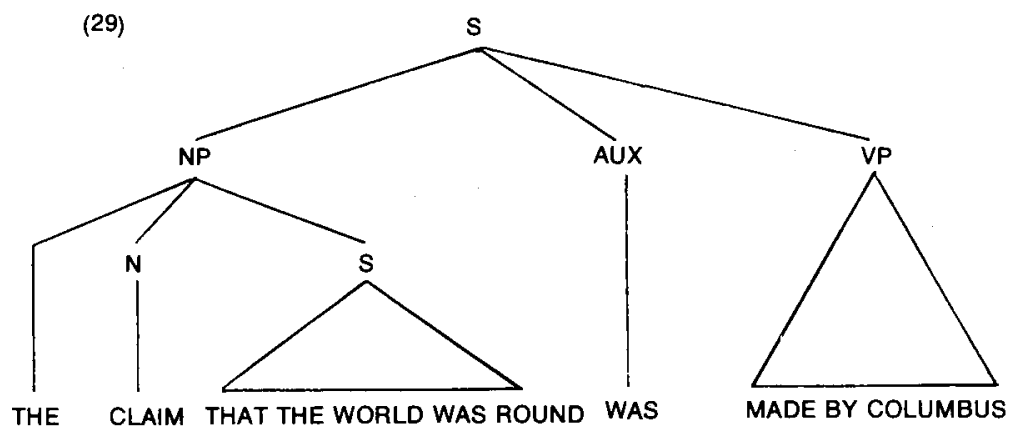

(30)

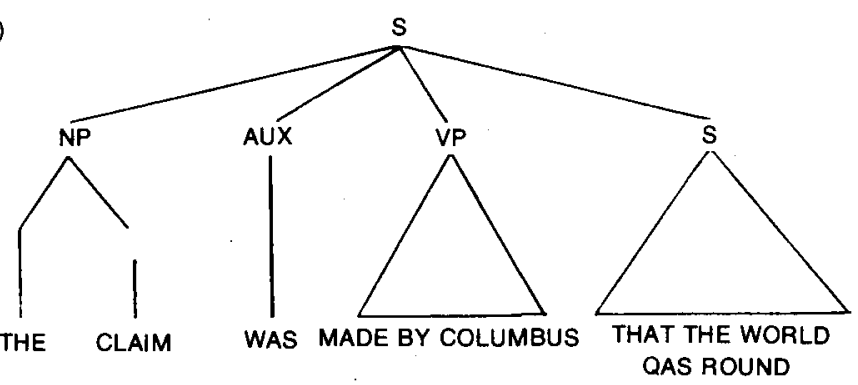

El principio cíclico queda garantizado si la transformación de extraposición precede a la regla de sustitución de it y a su vez ésta precede a la reflexiva (81). Lakoff, aunque también asignó la extraposición al ciclo,

(80) Cf. R. A. JACOBS and P. S. ROSENBAUM (1968, 172). J. ROSS (1966a, 289), basándose en P.S. ROSENBAUM (1967), ofrece la siguiente regla de extraposición:

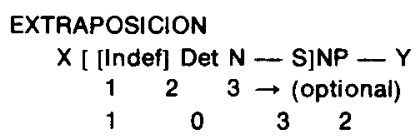

(81) Cf. R. A. JACOBS and P. S. ROSENBAUM (1968, 238): «lt would thus appear that the "it" replacement transformation must precede the reflexive transformation". Cf. R.A. JACOBS and P.S. ROSENBAUM (1968, 241-242): "A second argument for the cycle's existence can be made in terms of two other transformations which sould by now be very familiar to you: extrapositicion and $i t$ deletion. These are involved in the generation of such sentences 
ofreció un orden distinto: la extraposición era el último elemento de una cadena en la que se incluía la reflexiva pero que se iniciaba con la regla de sustitución de it (82). Para ello se apoyaba en la constricción universal de Postal (1968) y en otra constricción sobre las reflexivas que el propio Lakoff formuló. En la constricción universal de Postal una transformación que intercambie sujeto y objeto no permite que las piezas intercambiables sean idénticas: la reflexiva no puede someterse a transformación pasiva ya que ambas se excluyen mutuamente. En la constricción de Lakoff los dos sintagmas nominales que participan en la reflexiva tienen que estar dominados por el mismo nudo $O(83)$.

Por otra parte, McCawley asignó la extraposición al posciclo, en contraposición a las reglas de supresión de sintagma nominal equivalente y elevación del sujeto que eran cíclicas. En (31) y (32) se intercambian las transformaciones que suprime el sintagma nominal equivalente y la que eleva el sujeto (84). En (31) la elevación del sujeto debe aplicarse a $S_{1}$ antes que la supresión de sintagma nominal equivalente se aplique a $S_{0}$ (su configuración es (33). En (32) la supresión de sintagma nominal equivalente debe aplicarse a $S_{1}$ antes que la elevación del sujeto se aplique a $S_{0}$ (su diagrama es (35).

as It si obvious that John is late and That John is late is obvious from the same deep structure, very roughly that given below:

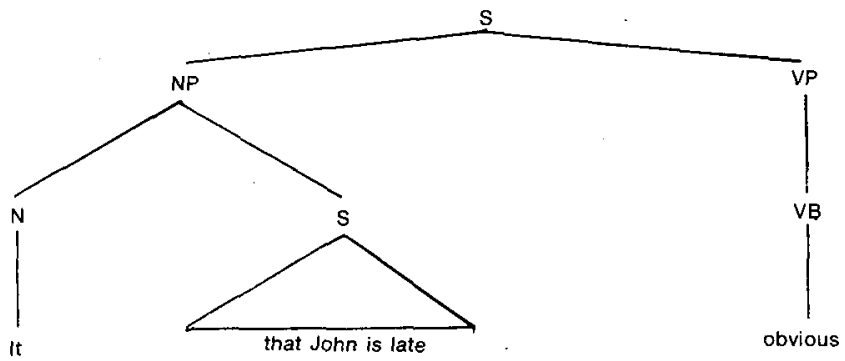

The extraposition transformation must precede it deletion and must be optional». Cf. También A. ROGERS (1971, 158-159).

(82) Ct. G. LAKOFF $(1966,62-86)$. D. T. LANGENDOEN $(1969,52-56)$, en contra de P. S. Rosenbaum, J. Ross, G. Lakoff y J. D. McCawley, no considera que la regla de extraposición sea optativa.

(83) La constricción de Lakoff está sometida a ciertas restricciones. Cf. G. LAKOFF (1966, 63-64 ss.).

(84) Cf. J.D. McCAWLEY (1969b, 252). La transformación de elevación del sujeto se aplica a ciertas oraciones que contienen una cláusula incrustada, desplazando el sujeto y el resto de la cláusula a la oración superior. Arthur seems to admire Spiro procede de una estructura subyacente en la que seem es un verbo intransitivo cuyo sujeto es la oración Arthur admires Spiro. G. J.D. McCAWLEY (1969a, 212): 
(31) Boris wants to seem to understand physics

(32) Boris seems to wants to understand physics

(33)

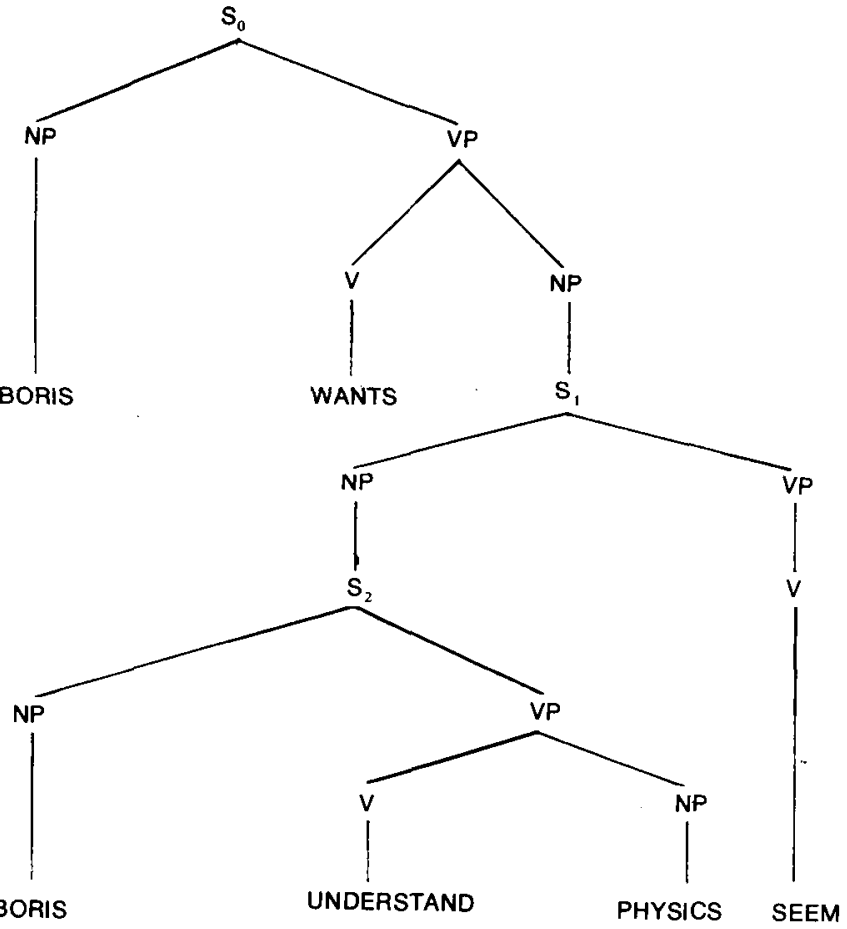

ORDEN:

A. ELEVACION DEL SUJETO

B. SUPRESION DEL SINTAGMA NOMINAL EQUIVALENTE

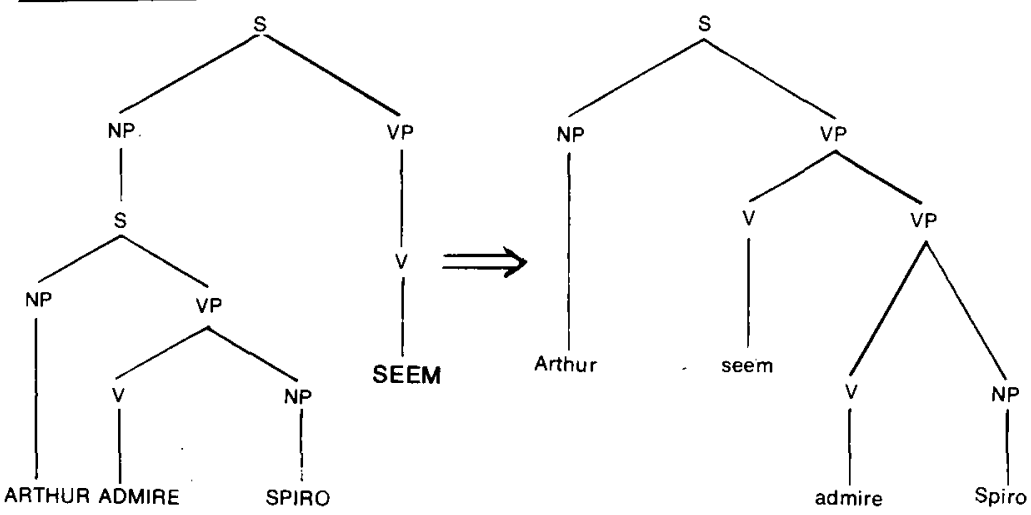


La supresión de sintagma nominal equivalente y la elevación del sujeto tienen que estar en el ciclo, ya que si una de las dos fueran precíclicas o poscíclicas todas las aplicaciones de una precederían a todas las aplicaciones de la otra, y al menos una de las dos últimas derivaciones sería imposible. En las reglas poscíclicas las aplicaciones de una transformación preceden a las de la siguiente, como sucede con la extraposición. Si ésta estuviera en el ciclo habría que asignar a ciertas oraciones una falsa estructura superficial. Por ejemplo, en (35) toda la secuencia que sigue a appears sería un constituyente en la estructura

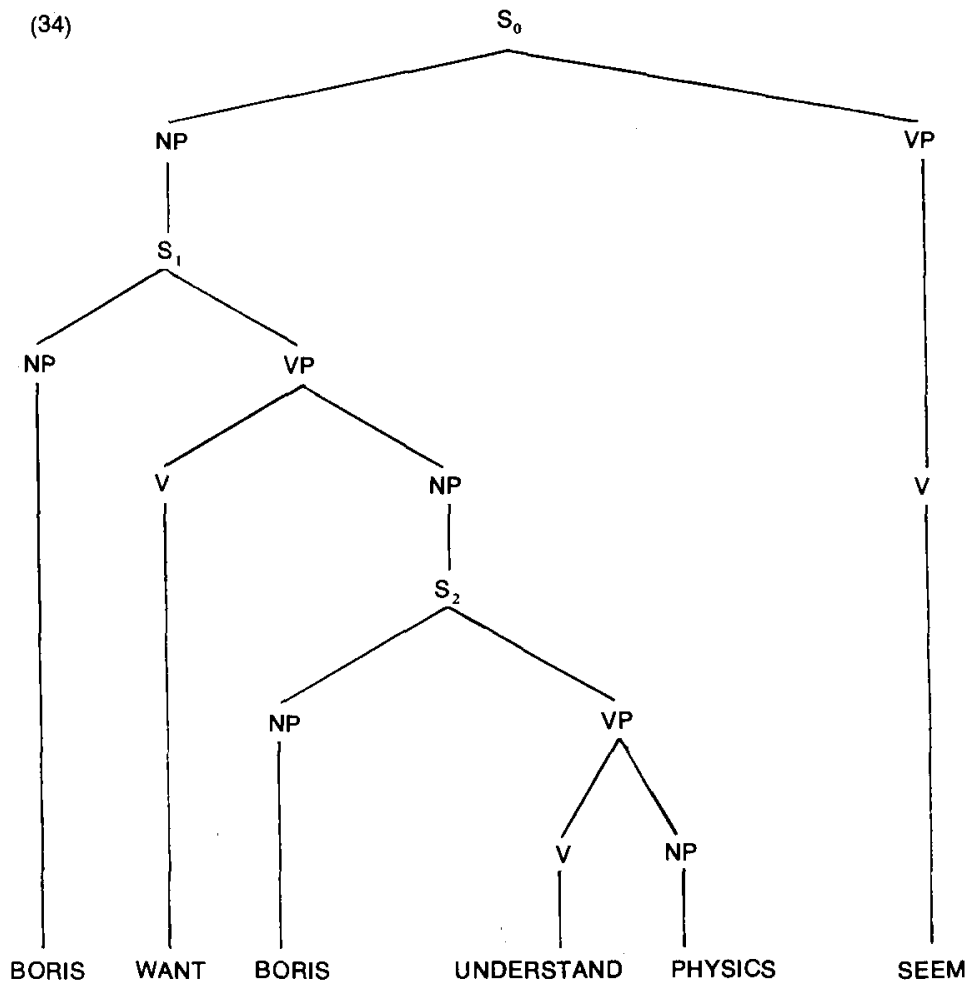

ORDEN:

A. SUPRESION DEL SINTAGMA NOMINAL EQUIVALENTE

B. ELEVACION DEL SUJETO

superficial, entonación que sería bastante ilógica en inglés, pues lo normal es hacerlo después de unlikely. 
(35) It appears to be unlikely that Nixon will send the marines to Botswana. Sin embargo, si se acepta la hipótesis de que la extraposición es poscíclica, se produce una estructura superficial que posibilita la entonación: el ciclo no afectaria a $S_{1}$, y su aplicación a $S_{0}$ produciría (37), la cual se convertiria en (38) mediante una transformación de extraposición, en la que appears to be unlikely es un constituyente superficial y el limite entonativo puede ir entre unlikely y that (85).
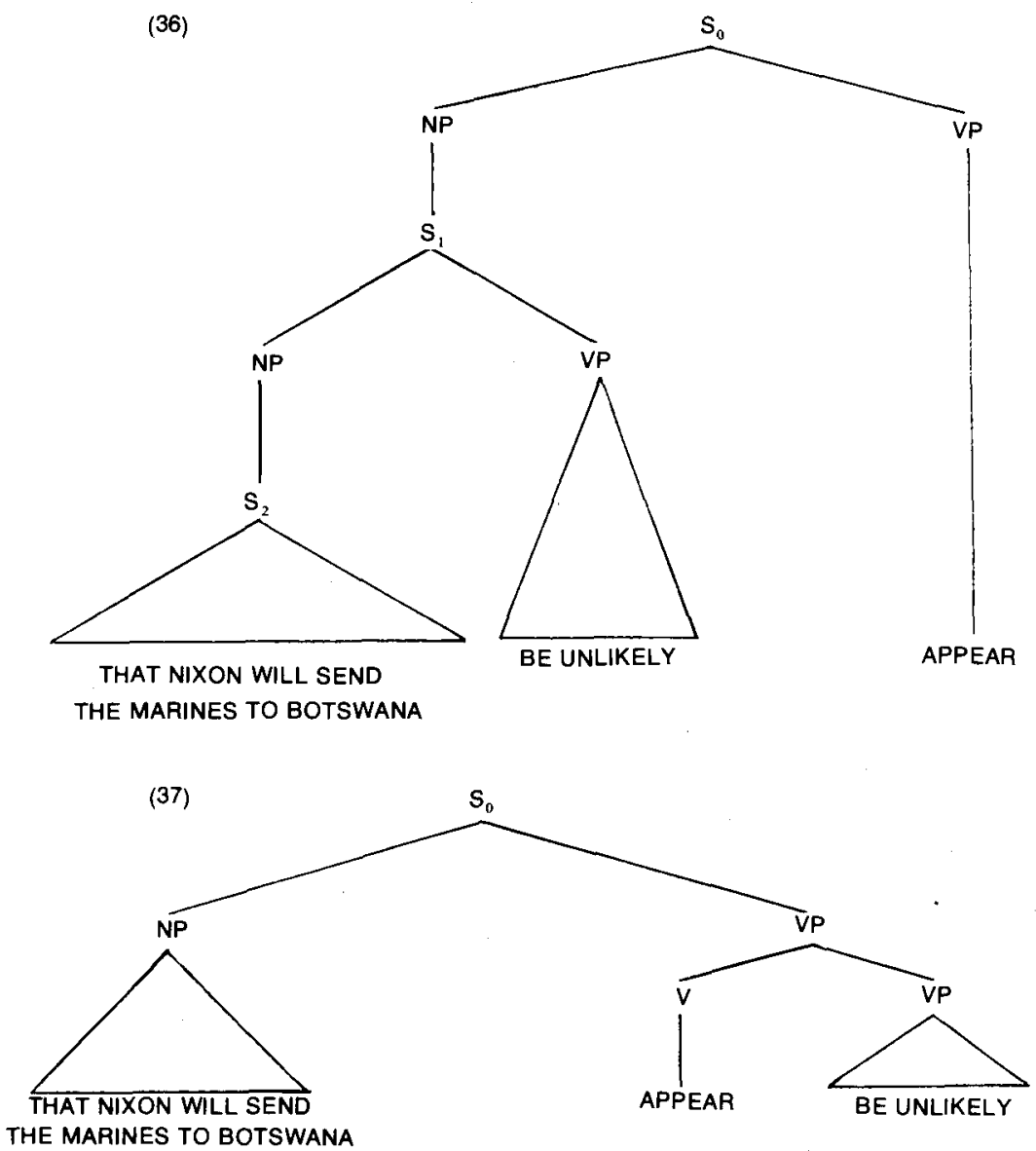

(85) O. MCCAWLEY (1969a, 213-215). 


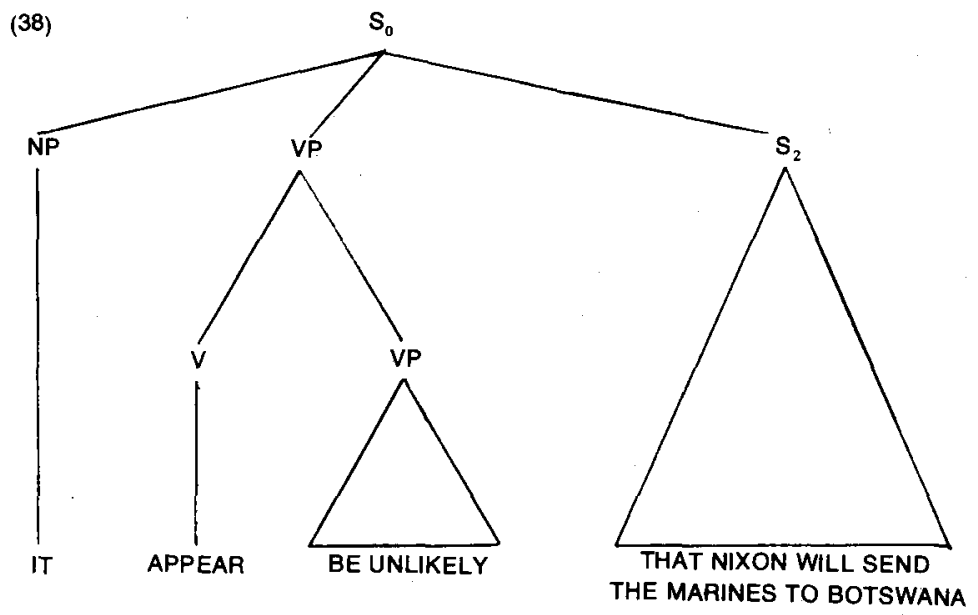

El otro universal formal objeto de mi exposición es el que Ross denominó la Rule of Tree-Pruning. Este lingüista observó una inadecuación en la estructura que la teoría transformatoria asignaba a un sintagma nominal de la forma his yellow cat:

(39)

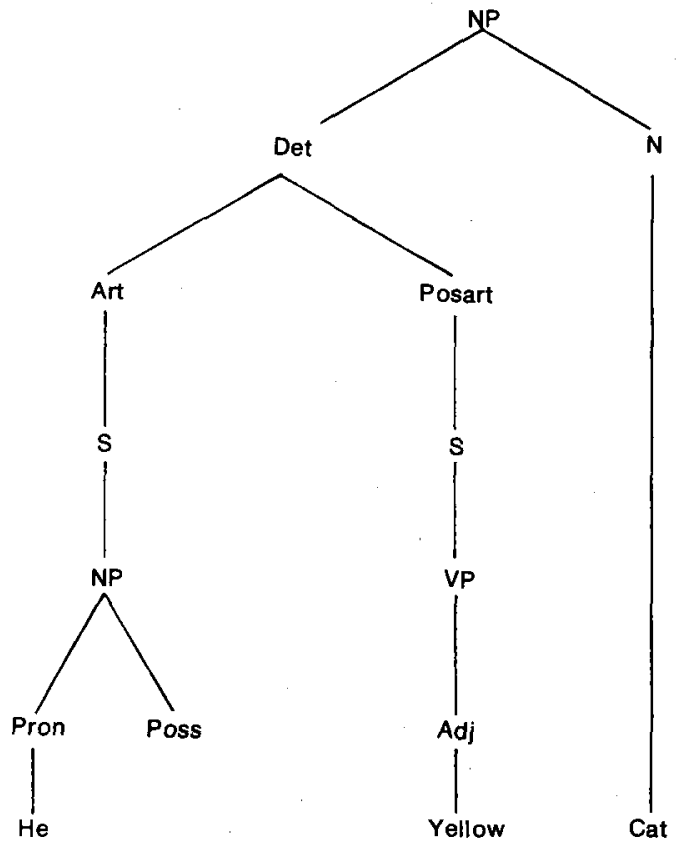


En (39) el posesivo 'su' y el adjetivo 'amarillo' están dominados por un símbolo $S$, y son ambos oraciones que se derivan de cláusulas relativas. Del mismo modo, la construcción 'su gato amarillo' surge de un sintagma nominal al que subyacen dos oraciones relativas: 'el gato que él tiene que es amarillo'. Ahora bien, Ross considera counterintuitive pretender que his, yellow y his yellow cat caterwauls incessantly sean oraciones. Para resolver esta incorrección propone que la teoría de la gramática conste de la metarregla siguiente:

(40) Suprimase un nudo incrustado $S$ que no se ramifique (i.e. que domine directamente a un sintagma nominal o a un sintagma verbal) (86).

Ross reconoce la deuda contraída con Lakoff por advertirle que estas reglas deben restringirse a oraciones incrustadas. De no ser así la convención (40) suprimiría el nudo $S$ en oraciones imperativas, ya que al eliminar el sintagma nominal sujeto la oración domina a un sintagma verbal. Esta regla no debe tener un lugar fijo en la ordenación del ciclo, ni aplicarse a secuencias en las que intervengan otras transformaciones de la gramática sino que debe concebirse como una condición sobre la buena formación de diagramas y operar en muchos lugares de la derivación de una oración. Siempre que una configuración de reglas produzca un símbolo $S$ que no se ramifique, la regla (40) actúa y borra ese símbolo, como sucede en (39), donde dicha convención funciona correctamente tachando el nudo $S$ de 'su' y de 'amarillo'. Ross menciona cuatro situaciones en las que existen razones poderosas para suprimir la estructura superior de los diagramas. Una de estas situaciones afecta a las oraciones comparativas, en las que se produce la supresión de oraciones no ramificadas que lleva a cabo la Rule of Tree-Pruning. Como esta situación exige la modificación de la metarregla (40), voy a seguir paso a paso la argumentación de Ross (87). Aunque en (41) el uso final de is es optativo, el sintagma nominal that

(86) Cf. J.R. ROSS (1966a, 289): “Delete any embedded node $S$ which does not branch (i.e. which directly dominates only NP or VP)".

(87) Las otras tres situaciones expuestas en J.R. Ross (1966a, 289-294) afectaban: (i) a los modificadores postnominales - sean adjetivos o sintagmas preposicionales-, que se derivan de cláusulas relativas siguiendo un proceso de reducción de dichas oraciones, y que tras aplicar optativamente la regla de extraposición se somete a la metarregla de supresión de oraciones no ramificadas (Rule of Tree-Pruning); (ii) a las partículas verbales, ya que como la regla de separación de partículas es obligatoria si el sintagma nominal es pronombre pero se bloquea si el sintagma nominal es complejo, la constricción del sintagma nominal complejo se somete a la supresión de oraciones no ramificadas, y (iii) al orden de las palabras en determinadas lenguas, como sucede en latín, que necesita de la Rule of Tree-Pruning. 
man sólo puede sufrir una transformación relativa y desplazarse al comienzo de la oración si el verbo is ha sido suprimido.

(41) John is taller than that man (is)

(42) a. He is a man who John is taller than

b. "He is a man who John is taller than is

Para comprender la agramaticalidad de (42b), Ross sostiene que las construcciones comparativas tienen oraciones negativas en su historia derivativa. La estructura profunda (44) subyace a las oraciones (41) y (43):

(43) John is tall to an extent to which that man is not (tall)

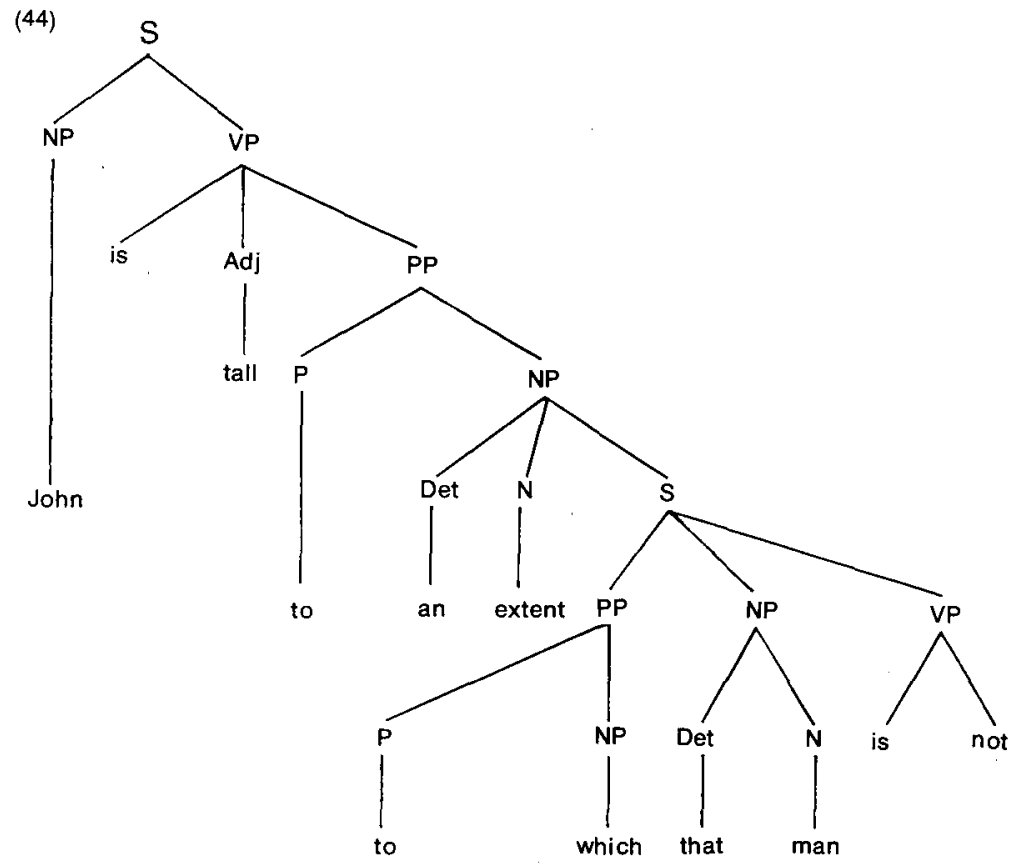

(44) es la presentación simplificada de una estructura a la que se le han aplicado varias transformaciones, como, por ejemplo, la convención que opcionalmente suprime 'alto' en la cláusula relativa. La transformación de introducción comparativa se aplica a (44) y la convierte en (46). 
(45) INTRODUCCION COMPARATIVA

$$
\begin{aligned}
& X-\left\{\begin{array}{l}
\text { Adj } \\
\text { Adv }
\end{array}\right\} \text { EN LA MEDIDA EN - QUE - Y - NO - Z } \\
& \begin{array}{lllllll}
1 & 2 & 3 & 4 & 5 & 6 & 7 \Rightarrow \text { (optativo) } \\
1 & 2+\text { más } & 0 & \text { que } & 5 & 0 & 7
\end{array}
\end{aligned}
$$
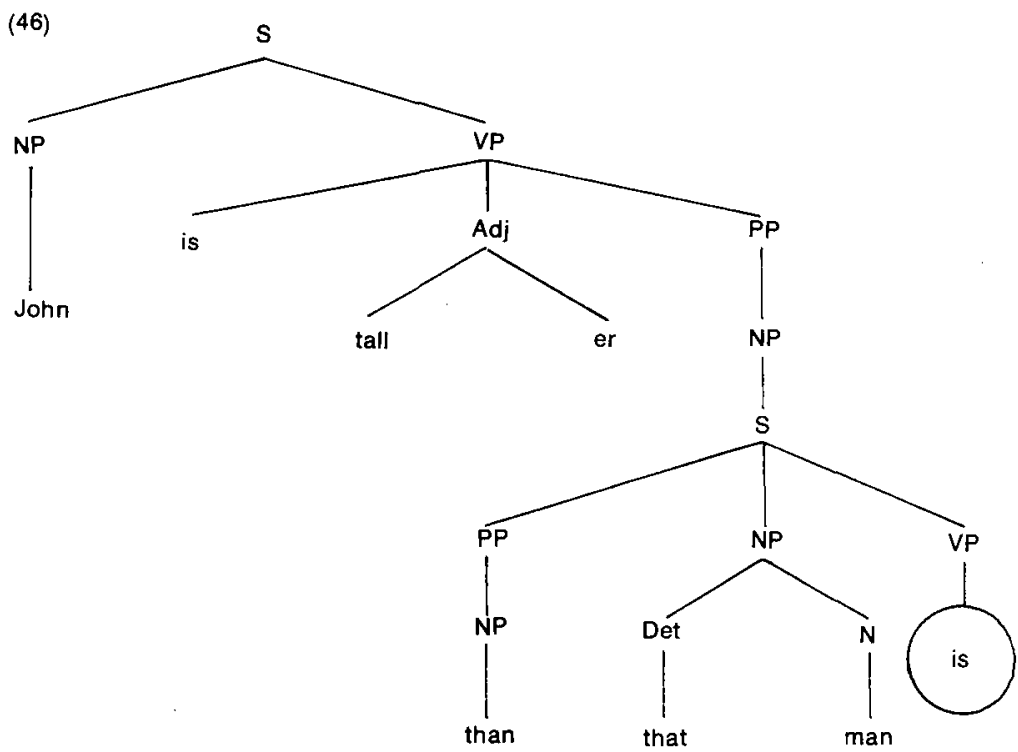

La regla (45) adjunta 'más' al adjetivo comparado o adverbio, sustituye el 'que' comparativo por el pronombre relativo 'que' y elimina 'en la medida en' y 'no'. El sintagma nominal 'ese hombre' no puede someterse a una transformación relativa en (46) debida a una restricción general sobre la formación de cláusulas relativas:

(47) Un sintagma nominal que es el sujeto de una oración incrustada (esto es, un sintagma nominal que está directamente dominado por un nudo $S$ antes que por el simbolo superior S) no puede someterse a transformación relativa (i. e. ser movido al principio de la oración) a menos que sea el primer constituyente de la oración de la cual es sujeto.

La restricción general (47) explica por qué el sintagma nominal 'la chica' se somete a una transformación relativa en (48a) -compárese 
con (48b)-, pero no en (48c) — compárese con la agramatical (48d)-

(48) A. I thought the girl was hungry

b. She is the girl who I thought was hungry

c. I thought that the girl was hungry

d. *She is the girl who I thought that was hungry

En (48c) el sintagma nominal 'la chica' no puede someterse a una transformación relativa porque la oración incrustada de la cual es el sujeto no se establece mediante un sintagma nominal sujeto sino mediante la cláusula que introduce 'que'. En cambio, el proceso se puede realizar en (48a) porque se aplica una regla opcional y se suprime la cláusula que introduce 'que'. La restricción (47), que es necesaria en la gramática para comprender la agramaticalidad de (48d), también explica por qué el sintagma nominal 'ese hombre' no se somete a una transformación relativa en (46): en la oración incrustada de la que es el sujeto, 'ese hombre' va precedido de 'que'. Para dar cuenta de que el sintagma nominal 'ese hombre' se somete a una transformación relativa si se suprime el verbo 'es' encerrado entre círculo en (46) es necesario reformular la metarregla (40) de supresión de nudo como $\left(40^{\prime}\right)$ :

(40') SUPRESION DE NUDO

Un nudo incrustado $S$ se suprime a menos que domine a un sintagma nominal y a un sintagma verbal.

La convención (40') actúa mediante una regla optativa que puede tachar el nudo circular 'es' de (46). Si esta regla se aplica a (46) el sintagma verbal que domina al elemento circular será también eliminado mediante una metarregla general que suprime simbolos no terminales. (49) es el diagrama resultante de las supresiones de 'es' y del sintagma verbal: 
(49)

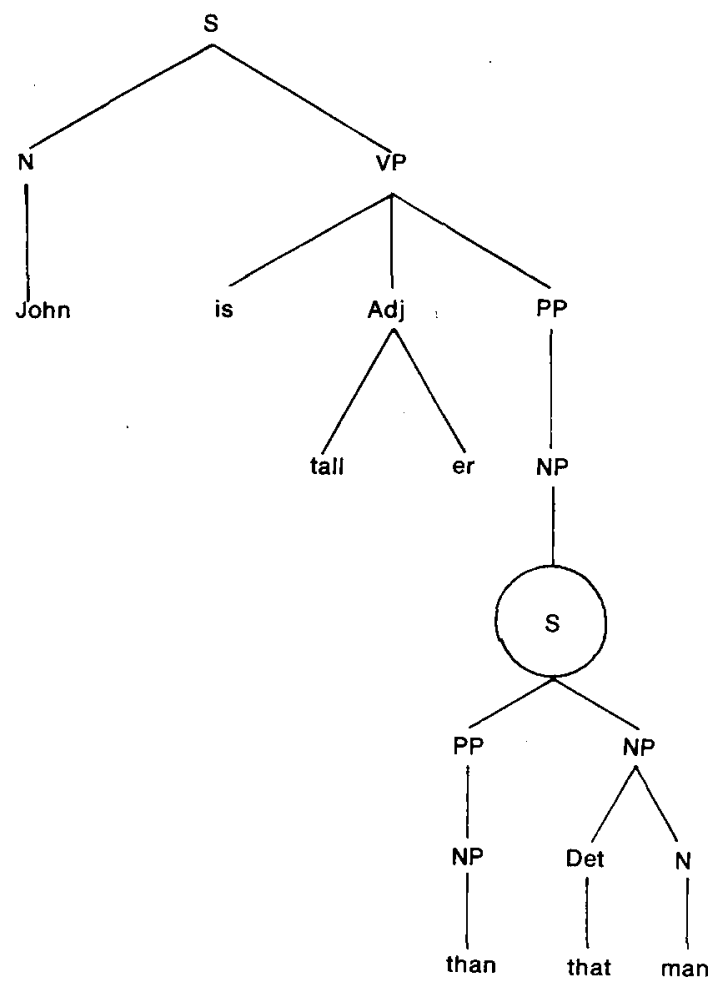

El nudo $S$, encerrado entre círculo en (49), se elimina mediante la regla (40'), ya que no domina a ningún sintagma nominal ni verbal. Su representación puede verse en (50). 


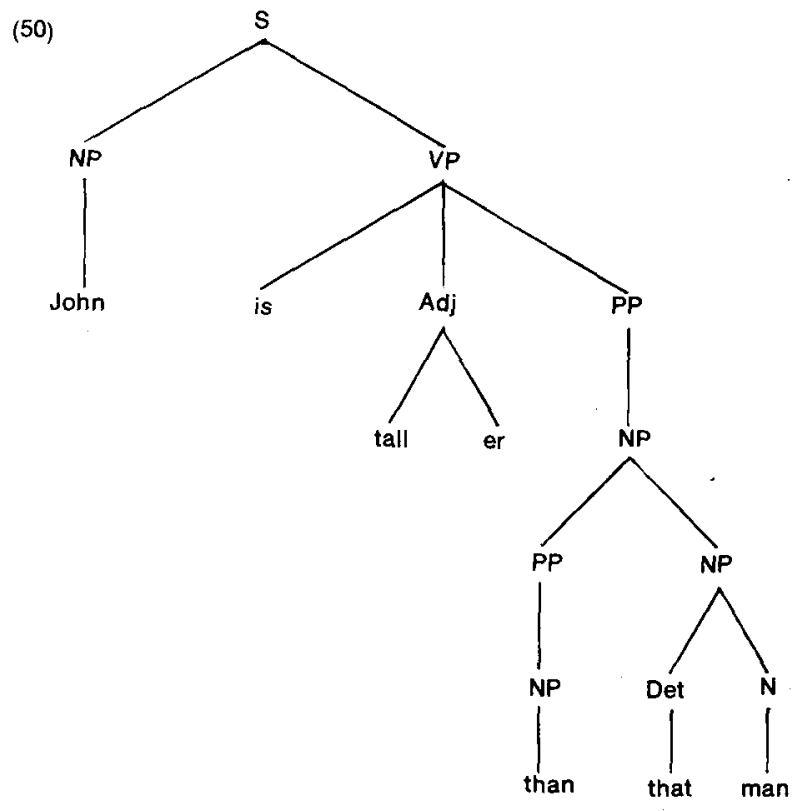

Al no existir oración incrustada más extensa en $(50)$, la restricción (47) no puede aplicarse, con lo que será posible someter el sintagma nominal 'ese hombre' a una transformación relativa para formar oraciones como (42a). Actualmente, no se puede dar cuenta de oraciones como (51) sin efectuar una revisión en la convención (40').

(51) a. To report the incident was wise of John

b. It was wise of John to report the incident

Las oraciones (51a) y (51b) se derivan de una estructura subyacente delimitada en (52) mediante una regla que suprime el sintagma nominal sujeto de la oración incrustada y que se somete a una condición de identidad con el sintagma nominal de la oración preposicional. En (51b) opera además la regla de extraposición. 
(52)

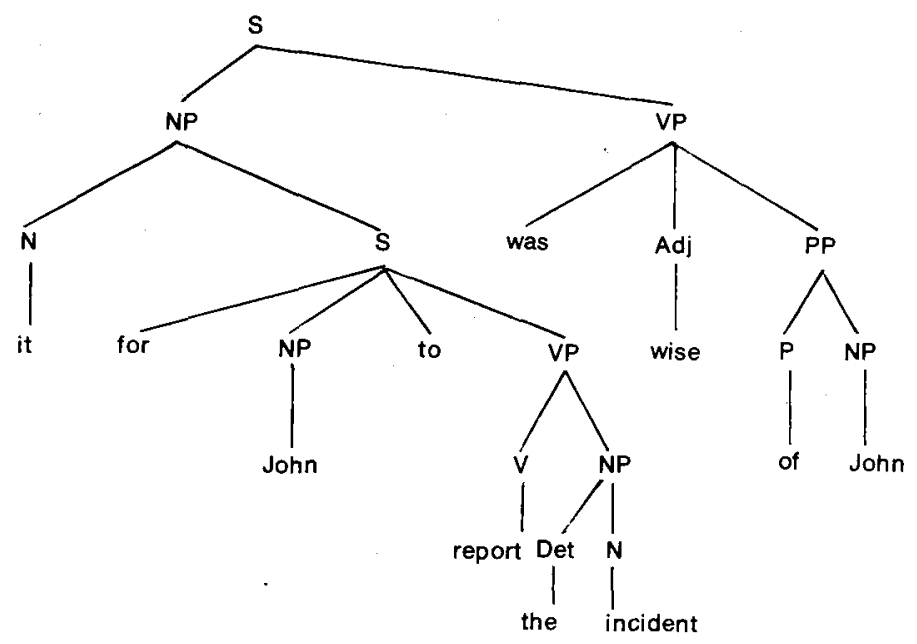

La regla que elimina el sintagma nominal sujeto de la oración incrustada convierte a (52) en (53)

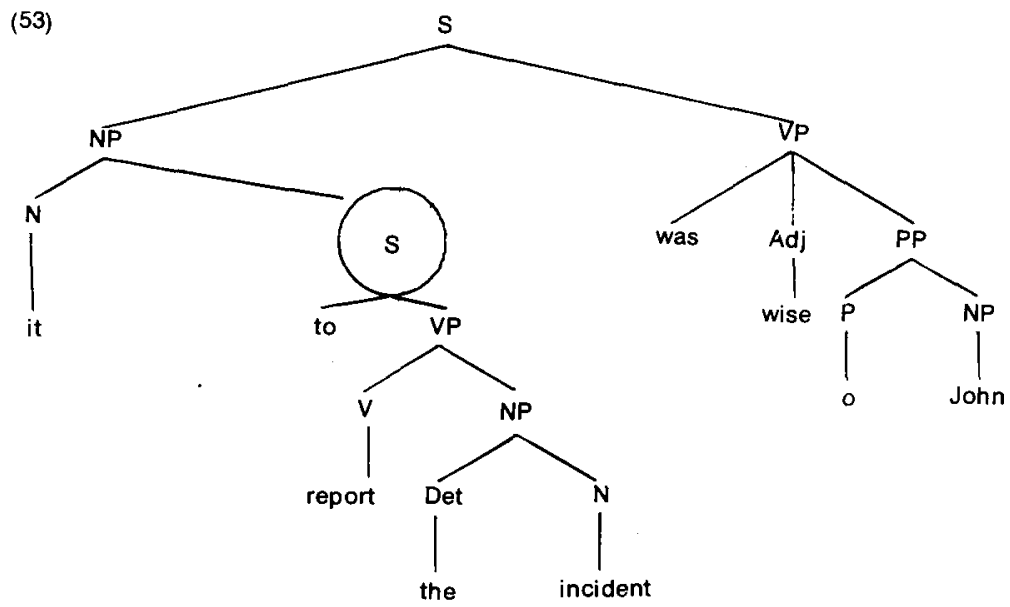


Si se elimina el nudo circular de (53), ya que no domina a un sintagma nominal ni a un sintagma verbal, entonces tampoco puede aplicarse la extraposición ni derivarse (51b). Por tanto, es necesario revisar (40') mediante lo que Ross denomina TABLA 1.

TABLA 1

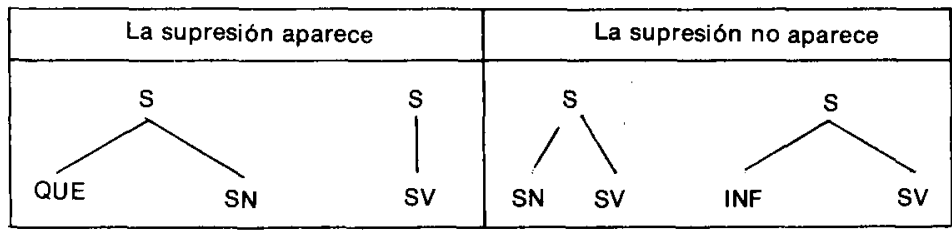

La condición (40") sintetiza los resultados de la tabla 1.

(40") Se suprime un simbolo incrustado $S$ a no ser que domine inmediatamente al sintagma verbal y a otro constituyente.

Así pues, Ross termina formulando tres reglas (40), (40') y (40") que son imprescindibles para suprimir nudos superiores de diagramas derivados. Aunque sean necesarios más datos para fortalecer esta hipótesis, estas metarreglas son convenciones universales antes que transformaciones particulares de una lengua (88).

La problemática del ciclo y/o posciclo, así como la Rule of TreePruning, son universales formales enormemente abstractos del discurso transformatorio (89). Pero el universal formal de los discursos transformatorios persigue fines. He dedicado varios escritos a demostrar que el objetivo final de los textos lingüísticos modernos - sean estructurales o transformatorios-, consiste en formalizar, desde el ámbito lingüístico y en tanto que lenguaje, la esencia del Espíritu y del

(88) Cf. J.R. ROSS (1966a, 294-299) y J.R. ROSS (1966b, 354-355).

(89) Sería incorrecto suponer que el ciclo o la convención de supresión de oraciones no ramificadas ocupen todo el espacio de los universales formales. Evidentemente, la nómina de tales universales podría ampliarse considerablemente: los principios jerárquicos de organización de oraciones, las restricciones que Ross asignó a las estructuras coordinadas como rasgo universal de las lenguas, las reglas intervinientes en la formación de oraciones negativas, los principios que rigen las interrogativas parciales, las condiciones de supresión que deben cumplir las transformaciones y la operación de tachado que Rosenbaum observó en aquéllas, el principio de $A$ sobre $A$, etc. 
Saber (90). Todos los discursos nacidos del pensamiento clásico han pretendido lograr este fin, y la imposibilidad de conseguirlo ha sido su gran frustración hasta los tiempos modernos. En época más reciente la fenomenología y el neopositivismo lógico entre los discursos categóricos, y el estructuralismo y la teoria transformatoria de la gramática entre los discursos lingüísticos han buscado de una u otra manera realizar aquella operación formal. Aunque la primera modalidad de los discursos transformatorios se apoya en principios más primitivos que la lógica neopositivista, las técnicas racionalistas y empiristas están en el inconsciente del neopositivismo, saben de los lazos fraternales que los unen y no desaprovechan cualquier ocasión de supervivencia. Así es fácilmente comprensible el continuo préstamo de nociones y el reconocimiento, no exento de ciertas distancias y mutuos ataques críticos, entre ambas modalidades de los discursos transformatorios. Un ejemplo elocuente lo constituye el hecho de que la problemática del ciclo - y la Rule of Tree-Pruning podría también ser aceptada sin dificultad-, sea reconocida como universal formal discursivo en el entramado de los textos transformatorios pertenecientes a una u otra modalidad. Las críticas efectuadas por Jackendoff sobre las hipótesis de Lakoff o Postal son siempre fricciones secundarias de carácter empírico que dejan incólume las bases del sistema lingüístico. Por eso, en el artículo más inteligente de cuantos se ha escrito sobre la historia de los textos transformatorios, Chomsky (1968b) ponía de manifiesto las escasas diferencias que existen entre todas las variantes de las gramáticas transformatorias.

Los universales formales son fuentes de la primera experiencia porque a través de los fines que persiguen se constituyen en la primera percepción que capta el ojo en la producción real del habla. En el instante en que Ross establece la necesidad de la Rule of Tree-Pruning para explicar que la oración (41) contiene una oración negativa y otra relativa (43), la metarregla de oraciones no ramificadas se convierte en una noción anterior a la producción real del habla. Cuando afirmo que la Rule of Tree-Pruning es anterior a la producción real del habla quiero decir que se trata de un universal a priori y mítico que sólo existe en la imaginación del constructor de un modelo, que en este caso es Ross. No es difícil entender que (41) no tiene por qué incrustar ninguna ora-

(90) Cf. M. CRESPILLO (1980a) y (1981), y en lo que concierne a los textos transformatorios, cf. M. CRESPILLO (1980b) y (1982). 
ción negativa ni relativa, a menos que se ponga un empeño particular en hacerlo para perseguir ciertos fines. Se puede pensar por un momento que la estructura profunda asignada por Ross a la oración (41) fuese una hipótesis imaginaria. Esto significaría que si no se pudiera incrustar una oración negativa en (41), la regla (45) de introducción de cláusulas comparativas -que suprimía la partícula 'no' de (44) y ampliaba el constituyente 'alto' de (44) en 'alto más', como puede verse en (46)-, no podría llevarse a cabo. Si esto fuera así (40), que es la primera formulación de la Rule of Tree-Pruning, no tendría razón de ser porque no existiria el símbolo $S$ y no podría entonces suprimirse ningún nudo $S$ que no se ramifique. Si tampoco se incrustara una oración relativa en (41), la restricción general sobre la formación de cláusulas relativas (47) sería inoperante, y, del mismo modo, sería innecesaria la segunda variante de la metarregla $\left(40^{\circ}\right)$ por la que un nudo incrustado $S$ se suprime a menos que domine a un sintagma nominal y a un sintagma verbal. En definitiva, si la oración comparativa no implicara relaciones negativas y relativas en su estructura subyacente, la Rule of Tree-Pruning sería innecesaria y proporcionaría un argumento empírico fundamental para apoyar la tesis de que los universales formales sólo existen en la imaginación de los constructores de modelos y de que se aplican en aquellos casos que conviene a la lógica formal de las teorías gramaticales (91). Para poner de manifiesto hasta qué extremos puede ejercer Ross un control sobre las oraciones comparativas me voy a apoyar en el artículo de Alarcos sobre El español 'que' (92). Distinguía este lingüista un/que/ ${ }_{1}$, transpositor de oraciones a nombres, un / que/ ${ }_{2}$, transpositor de oraciones a adjetivos y un / que/ ${ }_{3}$, que intervenía en las oraciones comparativas. El / que/ ${ }_{3}$ comparativo tenía como estructura subyacente una coordinada copulativa. Así (54) era para Alarcos el resultado de la refundición implícita de (55):

(54) Pedro es más altc que su padre (es alto)

(55) Pedro es alto y su padre es alto $\rightarrow$ Pedro es alto, su padre es menos alto $\rightarrow$ Pedro es más alto que su padre (es alto).

En principio no existen argumentos empiricos para rechazar que las construcciones comparativas son el resultado de una refundición iniciada en las cláusulas coordinadas copulativas y, sin embargo, la oración (54) tiene una estructura idéntica a la construcción (41) de Ross. ¿Cómo negar que la oración (41) de Ross 'Juan es más alto que ese

(91) Esta es una técnica epistemológica usual a la que denomino control de los modelos hipotéticos en M. CRESPILLO (1982).

(92) Cf. E. ALARCOS (1970, 192-206). 
hombre" no es el resultado de la cláusula cuya estructura se iniciaba en Alarcos como (55) 'Juan es alto y ese hombre es alto'? Y del mismo modo, ¿cómo rechazar que la construcción (54) de Alarcos 'Pedro es más alto que su padre' no es el resultado de la frase cuya estructura describe Ross como (43) 'Juan es alto en la medida en que su padre no lo es'? El interrogante fundamental es el de cómo no aceptar que la coordinación copulativa se sitúe en la base de las comparativas con el mismo derecho que la relativa y la negación. Estas cuestiones permiten suponer que en el interior de las comparativas no hay refundiciones, como propone Alarcos, ni nada oculto, como piensa Ross (93). Todo modelo que se desarrolla en virtud de hipótesis o supuestos, como sucede en la totalidad de los textos transformatorios, tienen la debilidad de permitir tantas alternativas como pueda ofrecer el autor que controle un discurso que él mismo construye. Por eso se pueden efectuar varias propuestas que implican diversos tipos de relaciones ocultas y que destruyen la hipótesis de Ross de que la Rule of Tree-Pruning puede concebirse como un universal formal del lenguaje. El enunciado (41) 'Juan es más alto que ese hombre' no contiene sólo la alternativa de Ross (43) 'Juan es alto en la medida en que ese hombre no es (alto)', ni la de Alarcos (55) 'Juan es alto y ese hombre es alto' $\rightarrow$ 'Juan es alto, ese hombre es menos alto', esto es, no contiene únicamente una oración relativa, negativa o copulativa, sino que puede contener también una relación causal (56), condicional (57) o concesiva (58).

(56) Juan es alto ya que ese hombre no (es)

(57) Si ese hombre es alto Juan es más (alto)

(58) Aunque ese hombre sea alto Juan es más (alto)

A pesar de que el proceso de relaciones podría seguir multiplicándose de acuerdo con presuposiciones y contextos diferentes, creo que es suficiente con reconocer en la profundidad de las comparativas relaciones coordinadas, causales, condicionales y concesivas, ya que el argumento de las comparativas como sustento de la Rule of TreePruning descansa exclusivamente sobre oraciones relativas y negativas.

La metarregla de supresión de oraciones no ramificadas, incorporada a las gramáticas transformatorias como una convención universal, es una noción imaginaria surgida del esfuerzo técnico que conlleva todo modelo controlable. El modelo puede llevar a cabo su propio

(93) Las estructuras profundas constituyen un ejercicio epistemológico destinadò a representar una práctica espacial. Cf. M. CRESPILLO (1982). 
control porque la problemática que interviene en el discurso pretende formalizar el espíritu. El ojo reconoce como fuente real del habla todos los fundamentos epistemológicos que el modelo necesita y, simultáneamente, permite que el universal formal se constituya en fuente de la primera experiencia y se encuadre en la producción real del habla mediante una técnica empirista (94). Es así como el universal formal garantiza la identidad "discurso/objeto": si los procedimientos cíclicos son universales de gramática y éstos son universales de lengua, el ciclo asegura la unidad del lenguaje y se convierte en el mejor reflejo del espíritu. La esencia del ciclo es inalterable en las modalidades sintáctica y semántica del sistema transformatorio porque el universal formal es un espacio idóneo para que el empirismo, el racionalismo y el neopositivismo se reconozcan en determinadas situaciones coyunturales favorables. En este sentido, el ciclo muestra una lógica abstracta a través de una convergencia categórica entre lo sucesivo y lo aplicativo. Los procedimientos de razonamientos, demostraciones y pruebas son la razón constitutiva del discurso sobre las matemáticas, y no en vano la sucesión es una categoría que proporciona el orden de los modelos en los discursos de las ciencias. Pero cuando se saca de este ámbito el orden sucesivo deja de ser una categoría constitutiva y se convierte en aplicativa. La sucesión del ciclo es resultado de una categoría aplicada a la teoría gramatical y no forma parte constituyente de ella, como sucede en los textos sobre las ciencias. Entender la sucesión como aplicación es el resultado de un proceso imaginario que confunde la generalidad teórica conceptual propia de los dominios científicos con la abstracción teórica propia de los ámbitos categóricos. Por lo tanto, la sucesión ordenada que interviene en el ciclo es una técnica empirista y un simple paso de abstracción epistemológica. Aunque Lakoff piense que la complejidad del ciclo no se da en la producción real de la lengua de la que hacen uso los hablantes (95), el proceso de confusión

(94) Este proceso explica lo que G. LAKOFF (1966, 127-132) denominó reglas ubicuas cuando estudió la transformación de supresión de it.

(95) Cf. G. LAKOFF (1966, 87): «adviertase que, igual que sucede con las reglas mismas en cuanto al orden en que se encuentran colocadas, el proceso por el que un ciclo sigue a otro no tiene lugar en un tiempo real: el ciclo de $\mathrm{O}_{3}$ precede al de $\mathrm{O}_{2}$ en el mismo abstracto sentido en el que una regla precede a otra; esto es, de igual modo que ocurre con la mayoría de los conceptos de la teoría de la gramática, el recorrer cíclicamente las reglas no pretende contar con un análogo físico en la producción real del habla, sino que únicamente pretende formar parte de la definición de lo que queremos decir al hablar de 'gramática'; y vamos a tratar de mostrar en lo que sigue que esta hipótesis acerca de la naturaleza del lenguaje, tan sumamente alambicada, es necesaria si queremos que toda una serie de datos que constituyen verdaderos lugares comunes adquiera sentido». Aunque Lakoff declara que no existe una homologia entre el orden cicliclo gramatical y otro posible orden cíclico 
"generalidad/abstracción", que concibe al modelo como un conocimiento en sí mismo, le permite afirmar, sin embargo, que descubrir las claves que encierra el ciclo ayuda a conocer los mecanismos internos de la gramática y a poner de manifiesto el proceso misterioso que encierra la naturaleza del lenguaje. El ciclo, la Rule of Tree-Pruning, el principio de A sobre A, etc., servirían para conocer la naturaleza del lenguaje. Pero el conocimiento de la producción lingüística se presenta como un conocimiento por modelos en el que el universal formal se comprende como un proceso abstracto y ordenado de purificación técnica de las gramáticas y su correlato evidente es un espíritu uno y puro, oculto en la naturaleza humana. Como eslabón de la cadena de purificación que constituyen las gramáticas transformatorias, el ciclo es un objeto producido. Los objetos producidos no son constitutivos de conocimiento sino simples aplicaciones. Por eso los lingüistas no pueden ponerse de acuerdo en determinar el orden de las transformaciones en el ciclo, ya que el orden no existe y sólo es una pura invención del discurso. El problema esencial no consiste en explicar si la transformación de extraposición es cíclica o poscíclica sino comprender su naturaleza de objeto producido inexistente en la realidad de las lenguas, y entender que su relevancia sólo tiene lugar en la imaginación de los constructores de modelos. El ciclo, un universal formal más, conformará la esencia de las lenguas y se tornará en objeto producido. Concebido como esencia y objeto producido, el ciclo constituye una parte del objeto real y un aspecto de la producción real de las lenguas. Los universales formales son objetos producidos abstractos surgidos de la extracción de la esencia del objeto real. Ocultos en las lenguas, en el espíritu uno y universal, constituyen la ldea oculta en la materia a la que hay que extraer y abstraer mediante operaciones formales. Cuando los discursos transformatorios hablan de principios pertenecientes a la gramática universal no quieren indicar que aquéllos se den uno por uno en todas las lenguas. Supongamos, por ejemplo, como hace Demonte, que la transformación de extraposición no existe en la lengua española. Sin embargo, dicha regla es un principio universal no porque

en la producción real del habla, sin embargo, los textos transformatorios que vengo analizando -incluido el de Lakoff_-, no formulan nunca delimitaciones entre la lógica de su discurso y la del objeto real. $Y$ si alguna vez se establecen fronteras - como acaba de hacer Lakoff-, es sólo en el entramado categórico del sistema, y de manera aislada y circunstancial, esto es, sin constituir nunca un principio metodológico. Al formar parte el ciclo de la definición de gramática, Lakoff está formulando un requisito lo suficientemente fuerte como para comprender que el ciclo es un universal formal utilizado por el lingüista como representación y reflejo del orden real en que los enunciados se producen en cualquier lengua. 
exista en todas las lenguas sino porque algunas aplican ese principio abstracto una vez que se ha logrado su extracción: el inglés hace uso de ella, mientras que el español no la necesitaría. Pero esta opción en la aplicación corrobora aún más que la lógica transformatoria es una técnica empirista caracterizada no sólo por un proceso de extracción y abstracción sino también por una aplicación a lo concreto de la abstracción que se extrae. Una vez que la transformación de extraposición se ha extraído y abstraído del ciclo como universal formal, la técnica empirista del discurso transformatorio la aplica a las lenguas concretas. Por eso carece de importancia determinar si el ciclo es innato o no, ya que el carácter innato de la Idea es menos importante para el neopositivismo que la extracción propia de la Idea. Los semánticos transformatorios no sienten la necesidad de relacionar el ciclo con ninguna estructura innata porque lo importante es delimitar el universal formal en sí como epistemología de un modelo lógico que es un modelo producido. La opción que tienen de aplicar o no los universales formales extraídos forma parte del reconocimiento empirista. Las gramáticas particulares reconocen a la gramática universal mediante sus técnicas aplicativas y ésta reconoce a aquéllas a través de su técnica de extracción. El espíritu se reconoce en sus manifestaciones, y éstas se identifican entre sí como manifestaciones de un mismo espíritu. Los universales formales y sustantivos perseguirán la aprehensión esencial de la Idea como resultado de un proceso confluyente que garantiza la unidad de la teoría. Se trata de una confluencia unitaria en la que el universal formal se centra sobre el lado interior del objeto mediante una técnica formal y el universal sustantivo se sitúa en torno al lado exterior del objeto mediante una técnica de contenido. Esta convergencia permite reconocer que las dos clases de universales son aspectos diferentes de una misma lectura constituida por técnicas de aplicación que logran la unidad a través del reencuentro entre el formalismo y el sustancialismo implícitos en lo interior y lo exterior del objeto. Esta unidad se lleva a sus límites extremos con la hipótesis que Bach denominó Universalist-Unitarian, a pesar de las declaraciones explícitas que este lingüista formuló contra los universales formales y sustantivos.

Ya Chomsky sugirió la posibilidad de que los estudios básicos de las lenguas coincidieran en lo fundamental (96), y McCawley (1968a) for-

(96) Cf. N. CHOMSKY (1967a, 326): «Parece muy probable que las gramáticas se encuentren sometidas a otras condiciones muy severas [...]. Por ejemplo, puede suceder (como de hecho se suponía tradicionalmente) que las estructuras básicas sólo puedan diferir muy ligeramente de una a otra lengua; entonces, reduciendo lo bastante el margen de posibles estructuras básicas, cabría la posibilidad de formular definiciones muy generales de las 
muló la necesidad de una transformación de elevación del predicado en función del reducido número de categorías sintácticas existentes en la estructura profunda. Esta reducción categórica fue de una importancia excepcional para la constitución de la hipótesis universal unitaria: las «Grammars of English traditionally maintain a sharp divition between nouns, verbs, and adjectives. It is my purpose here to demonstrate that the differences between these 'parts of speech' exist only on a relatively superficial level and that the fundamental dichotomy underlying the distinctions is of a quite different sort. By saying 'sentences' rather than 'English sentences', I intend to suggest that the deep structures of sentences in different languages are identical; that is, I am subscribing to the idea of a universal set of base rules" (97). La propuesta de un conjunto universal de reglas de base era ya conocida en los textos cartesianos, para los que las lenguas diferían en modos de expresión pero no en pensamientos (98), y en la gramática de PortRoyal, para la cual la estructura profunda que expresa el significado es común a todas las lenguas ya que es una simple reflexión sobre las formas del pensamiento. Durante esta coyuntura histórica se subrayó la identidad de la estructura profunda que sirve de base a una variedad de formas superficiales en lenguas diferentes, y dicha identidad se relacionó con el problema de cómo expresar las conexiones semánticas significantes entre los elementos del habla (99). Hay una estructura básica común a todas las lenguas que refleja la estructura del pensamiento, esto es, existe «un conjunto uniforme de relaciones en el que, en cualquier lengua, pueden entrar las palabras que corresponden a las exigencias del pensamiento" (100). La primera modalidad de los discursos transformatorios defiende que la interpretación semántica de una

categorías que funcionan de 'símbolos no terminales' en las reglas del componente categorialm.

(97) Cf. E. BACH $(1967,91)$.

(98) Cf. N. CHOMSKY (1966, 75, nota 63).

(99) Cf. N. CHOMSKY (1966, 82). Sólo cambia la aplicación de las transformaciones, pero no los principios que las gobiernan, que son universales. Asi «las reglas transformatorias que convierten una estructura profunda en superficial pueden variar de una lengua a otra. La estructura superficial que resulta de estas transformaciones no expresa directamente las relaciones de significado de las palabras, desde luego, excepto en los casos más simples. La estructura profunda que sirve de base a la expresión efectiva, estructura que es puramente mental, es la que lleva consigo el significado semántico de la frase. Sin embargo, esta estructura profunda se relaciona con las frases efectivas en el sentido de que cada una de las proposiciones abstractas que la componen podría efectuarse directamente como un juicio proposicional simplex.

(100) Cf. N. CHOMSKY (1966, 97 y 98). 
oración es una peculiaridad de la semántica universal que está determinada por relaciones gramaticales de un «tipo que no está en absoluto claro" (101). Cuando Bach habla de conjunto universal de reglas básicas no se refiere al conjunto de relaciones que Chomsky lee en Port-Royal, ni al significado que este lingüista da a las palabras «interpretación semántica». El problema fundamental que se desprende del texto de Bach es el de comprender qué hay detrás del conjunto universal de reglas de base así como del reducido número de categorías que se asignan a todas las lenguas, tanto si existe o no interpretación semántica, como si aquéllas se determinan o no por sus relaciones gramaticales. La argumentación central de Bach hace referencia al hecho de que las estructuras profundas de lenguas diferentes son idénticas ya que existe un conjunto universal de reglas básicas. Pero su argumentación contiene una doble incoherencia, una interior a su propia problemática y la otra ajena a ella. La primera confusión se centra en torno a la propia utilización del término estructura profunda: Bach no tiene en cuenta que la estructura profunda, delimitada a través de las condiciones definitorias de Katz y Postal (1964) y Chomsky (1965) -i.e. forma y función, restricciones selectivas y de coaparición, inserciones léxicas y generalizaciones transformatorias-, no es más que un universal formal. Evidentemente resulta contradictorio que Bach se sirva del término estructura profunda y, sin embargo, subraye que el universal formal es insostenible. La segunda incoherencia tiene que ver con la identidad entre el objeto producido y el objeto real, esto es, con la confusión entre el discurso y su objeto. Este lingüista identifica su supuesto método, que en realidad es una técnica, con otra realidad supuesta, es decir, identifica las reglas básicas con la estructura profunda - la expresión de las mismas ideas por parte de las lenguas-, a la que se concibe como un objeto real.

La primera etapa de su argumentación consiste en delimitar que los nombres se derivan de cláusulas relativas: los "noun phrases with nouns as their heads are exactly like noun phrases with verbs and adjectives (or their derivatives) as heads in their underlying form» (102). La estructura profunda de (59) es (60 y la de (61) es (62):

(59) I know a seller of cactuses/a cactus-seller

(60) I know someone who sells cactuses

(61) We noticed an irregularity

(101) Cf. N. CHOMSKY (1967a, 285).

(102) Cf. E. BACH $(1967,91)$. 


\section{(62) We noticed something that was irregular}

¿Por qué la técnica de que hace uso Bach para identificar los nombres con las cláusulas relativas implica siempre que aquéllos se derivan de éstas? (103). ¿Por qué no puede suceder lo contrario si el texto de Bach carece de argumentos? Con los datos de que se dispone en la actualidad no se puede refutar razonablemente que los niños aprenden en primer lugar categorias sustantivas antes que cláusulas relativas, esto es, no se puede rechazar que aprenden antes la lógica del sentido que las estructuras sintácticas. Ciertos hechos empíricos, aunque tan hipotéticos y míticos como los del propio Bach, podrían apoyar una tesis opuesta. En español existen muchas cláusulas relativas que no admiten la transposición a adjetivo, ni siquiera mediante elementos sinónimos imaginarios:

(63) No veo la escalera con que tropezaste

$\left(64{ }^{*}\right.$ No veo la escalera tropezadora

Además, ¿acaso no se omite cierta información cuando (59) se deriva de (60) o cuando (67) lo hace de (68)? La información que proporciona someone en (60) o 'alguien' en (68) es mucho más imprecisa que la llevada a cabo por 'vendedor' o 'mayordomo'. Mientras que en (60) someone who sells cactuses, es un cactus-seller o a seller of cactuses, en (68) 'alguien que es mayordomo' es un 'mayordomo'. ¿Dónde está entonces la nominalización verbal que existe en (60)? $Y$, por consiguiente, ¿cómo el nombre que se deriva de la cláusula relativa es un derivado verbal o un derivado de toda la oración incrustada, mientras que en (67) este proceso se desconoce?

(67) Conozco a un mayordomo

(68) Conozco a alguien que es mayordomo.

Uno de los resultados más importantes de la argumentación imaginaria de Bach consiste en suponer que los sintagmas nominales con verbo, adjetivo o nombre son idénticos en la estructura profunda $y$, consiguientemente, en admitir «a system involving three fundamental kinds of entities in the deep structure: sentences, terms and predicates or 'contentives'. Terms are essentially involved in what we call noun phrases, while contentives correspond to the three major lexical categories of nouns, verbs, and adjectives» (104). Además de las oraciones,

(103) Cf. E. BACH (1967, 93-104).

(104) Cf. E. BACH $(1967,91)$. Los contenedores, los nombres, los verbos y los adjetivos se eligen en virtud de constituir las "major lexical categories". Se comienza de este modo a vislumbrar los primeros intentos de lograr la unión "sintaxis/semántica" propugnada por la variante neopositivista para oponerse a las fronteras que delineo la sintaxis transformatoria. 
de los términos, y de los predicados o contenedores, la hipótesis de Bach contiene un conjunto de operadores y variables. Pero la hipótesis universal unitaria es también explicativa: delimita, por un lado, que el aprendizaje de una lengua consiste en la búsqueda por parte del niño de las transformaciones que derivan las estructuras superficiales de su lengua del conjunto de estructuras básicas universales, y establece, por otro, que lenguas tan distintas como el nootka, el japonés o el inglés no se diferencian porque posean respectivamente una, dos o tres categorías léxicas principales, pues al unificarse las tres categorías en una sola estas lenguas han de tener forzosamente la misma estructura profunda. Esta hipótesis universal y unitaria es una mezcla de universales formales y sustantivos y, por tanto, participa de la misma imagen mítica que convierte en ilusoria la problemática de los discursos transformatorios universales. Como sucede en los textos de la primera modalidad, la problemática tampoco sufre alteración en el discurso de Bach: "no one, I think, would seriously maintain the position that there are no universal concepts in linguistics whatsoever, since this would be tantamount to a denial of the possibility of any rational undesrtanding of language in general", y se origina, además, mediante una oposición inicial al empirismo estricto, ya que si no se acepta el universal lingüístico «linguistics would be a discipline which had no subject matter apart from the study of individual languages, and even here it would be a complete mystery how knowledge about one language could throw light on another (as it does)" (105). Rechazar el universal lingüistico es renunciar a la riqueza de la libertad formal del modelo. Por eso Bach, tras criticar la concepción de los universales formales y sustantivos expuesta en Katz y Postal (1964) y Chomsky (1965), dirá que la lingüística sólo puede pretender que las gramáticas de las lenguas se seleccionen a partir de un conjunto de objetos que satisfacen ciertas especificaciones estrictamente formales, y que después los elementos concretos de cada gramática serán completamente arbitrarios al pasar de una lengua a otra. En cuanto a los universales sustantivos Bach critica la tesis de que todas las lenguas comporten el mismo conjunto de elementos semánticos y los coloca en el extremo opuesto a los formales sin entender que ambos universales no son más que el interior y el exterior de lo Mismo. En una actitud típica del reconocimiento fraternal

El contenedor es una categoría cuya naturaleza es equivalente a la del predicado en lógica simbólica. Cf. E. BACH $(1967,115)$ : los contenedores "are quite like the predicates of logic or the 'full words' of traditional Chinese grammar".

(105) Cf. E. BACH $(1967,113)$. 
que surge frecuentemente entre el neopositivismo y el racionalismo cuando está en peligro la supervivencia de uno de ellos, Bach defiende que esta hipótesis es preferible a la de que las lenguas no compartan ningún elemento sustantivo. La verdad está siempre en un término medio: parece lógico que lo que se comparta sean sólo algunos elementos sustantivos. De este modo la hipótesis universal unitaria no contiene ningún rechazo de los universales formales y sustantivos (106). Bach no admite que las gramáticas seleccionen los elementos concretos de un conjunto de objetos formales y sustantivos. $Y$ aunque tampoco acepta la técnica empirista que extrae los universales, en cambio sí aplica determinados principios a cada lengua concreta. La propuesta de Bach, basada en los lingüistas de campo, de que las similitudes entre las lenguas tienen que ser más llamativas, manifiestas - notables que sus diferencias, es lo mismo que propone cualquier discurso de la primera modalidad. Lo que hace Bach es sustituir una técnica empirista, que abstrae, extrae y aplica, por otra neopositivista para la cual el universal formal o sustantivo es una forma a priori, esto es, una esencia del espiritu que se sitúa ante el ojo sin que éste tenga que trabajarla, ya que aquélla es el significante último del Lenguaje. Así se explica que el verdadero problema de Bach no consista en poder delimitar o no los universales como formales o sustantivos sino concebir la esencia de constitución del universal como una categoría dada de antemano $y$, por lo tanto, una categoría siempre dispuesta para ser aplicada posteriormente a las lenguas. De este modo, el universal formal o sustantivo, como lados del Uno, se contiene dentro de los enunciados neopositivistas estrictos de la segunda modalidad tanto como en los enunciados racionalistas de la primera. Sus diferencias sólo ra-

(106) Cf. E. BACH (1967, 113): Las «grammars of natural languages are chosen from a set of objects meeting certain purely formal specifications: there are such and such components. the rules in the varios components meet certain formal conditions, and so on. But the elements ocurring in these grammars are completely arbitrary from one language to another. This view is patently false, as is shown every time a field linguist encounters a new language. Given the logically or physically possible sets of elements available at all levels -phonological, semantic, syntactic_- the similarities among languages are far more striking than their differences [...]. One frequent statement is that each language makes some undetermined selection from a stock of universal elements. This a completely empty claim, of course, without an exhaustive specification of what these elements are. Otherwise, we can simply list all elements that have ocurred in the descriptions of particular languages and say that this is a partial set of such universal elements awaiting completion as we describe more languages. Obviously, there is no way to refute the statement that the universal set of elements comprises simply those which have been postulated for individual languages and which might be postulated in the future". 
dican en los respectivos procesos de determinación: en un caso el a priori es el elemento técnico operativo, y en el otro hay que aplicar la extracción de la esencia que se abstrae. Pero los resultados van a ser idénticos, hasta el punto de que Bach necesita formular tres hipótesis sobre la naturaleza de la gramática universal que hacen afirmaciones progresivamente más fuertes y empíricamente diferentes sobre la capacidad innata del hablante de una lengua, $y$ en las que cada una de esas hipótesis implica a la que le precede: «a) The base rules for any languages are constructed out of a fixed set of elements; $b$ ) there is a fixed set of universal grammatical relations such as subject-of, object-of. The rules of the base are constrained so as to express just this set of relations according to universal definitions $y \mathrm{c}$ ) the actual rules of the base are the same for every language (107).

(107) Cf. E. BACH $(1967,113-114)$. 


\section{REFERENCIAS BIBLIOGRÁFICAS}

ALARCOS, E. (1970), Estudios de gramática funcional del español. Madrid, Gredos.

ANDERSON, J. M. (1970), The Grammar of Case. Towards a Localist theory. Cambridge, C. Univ. Press.

BABCOCK, S.S. (1970), The Syntax of Spanish Reflexive Verbs. The Hague, Mouton.

BACH, E. (1967), “Nouns and Nouns Phrases", en Bach and Harms (eds.), págs. 91-122.

-and Harms, R.T. (eds.) (1968), Universals in Linguistics Theory. New York, Holt, Rinehart and Winston, INC.

BAJTIN, M.M. (Voloshinov, V.N.) (1976), El signo ideológico y la filosofía del lenguaje. Buenos Aires, Nueva Visión.

BENDIX, E.H. (1970), "The Data of Semantic Description", en Steinberg and Jakobovits (eds.), págs. 393-410.

BERKELEY, E. (1974), Principios del conocimiento humano. Buenos Aires, Aguilar.

CASSIRER, E. (1971), Filosofia de las formas simbólicas. México, F.C.E.

- 1972. Las ciencias de la cultura. México, Breviarios del F.C.E.

CONTRERAS, H. (Comp.) (1971), Los fundamentos de la gramática transformacional. México, S. XXI.

CRESPILLO, M. «Predominio lingüístico e interdisciplinariedad», Ciencias y Letras, n. ${ }^{\circ}$, año 1, 1981, pp. 25-31. 
CRESPILLO, M. (1980b), "La confusión del pensamiento y la realidad en los textos lingüísticos», Analecta Malacitana, Vol. V., 2, 1982, pp. 229253.

-(1981), «La imagen de la comunicación en el estructuralismo lingüístico", Verba, 1982, en prensa.

-(1982), Problemas de gramática transformatoria. Control y Reproducción, Agora, Málaga, 1983, en prensa.

CHOMSKY, N. (1958), "A Transformational Approach to Syntax", en Fodor and Katz (eds.), págs. 211-245.

-(1965), Aspectos de la teoria de la sintaxis. Madrid, Aguilar, 1970.

-(1966), Lingüistica cartesiana. Madrid, Gredos.

-(1967a), «La naturaleza formal del lenguaje», en Gracia (comp.), págs. 275-332.

-(1967b), “Observaciones sobre la nominalización”, en Sánchez de Zavala (comp.), (1), 1974, págs. 133-187.

-(1968a), El lenguaje y el entendimiento, Barcelona, Seix Barral, 1971.

-(1968b), «Deep Structure, Surface Structure and Semantic Interpre.tation», en Steinberg and Jakobovits (eds.), págs. 183-216.

DELEUZE, G. (1968), Spinoza y el problema de la expresión. Barcelona, Muchnik ed.

DEMONTE, V. (1977), La subordinación sustantiva. Madrid, Cátedra.

DESCARTES, R. (1968), Discurso del método. Barcelona, Bruguera.

- (1973), Meditaciones metafísicas. Buenos Aires, Aguilar.

FANO, G. (1968), Neopositivismo, análisis del lenguaje y cibernética. Barcelona, A. Redondo ed.

FILLMORE, CH. J. (1966), «Una teoría moderna de los casos», en Contreras (comp.), págs. 45-65.

-(1967), "The case for case», en Bach and Harms (eds.), págs. 1-88.

-(1968a), "Lexical Entries for Verbs», Fol, 4, págs. 373-393.

-(1968b), «Types of Lexical Information», en Steinberg and Jakobovits (eds.), págs. $370-392$.

-(1969), "Verbs of Judging: an Excercise in Semantic Description", en Fillmore and Langendoen (eds.), págs. 273-289.

- (1971), "Algunos problemas de la gramática de casos», en Sánchez de Zavala (Comp.), (II), 1976, págs. 171-200.

-and Langendoen, D.T. (eds.) (1971), Studies in Linguistic Semantic. New York, Holt, Rinehart and Winston, Inc.

FODOR, J.A. and Katz, J.J. (eds.) (1964), The Structure of Language. Readings in the Philosophy of Language. Englewood Cliffs, Prentice-Hall, Inc.

GRACIA, F. (comp.) (1972), Presentación del lenguaje. Madrid, Taurus. 
GREENBERG, J.H. (ed.) (1963), Universals of Language. Cambridge de Mass., MIT Press., 1966.

- (1963), «Some Universals of Grammar with Particular Reference to the Order of Meaningful Elements", en Greenberg (ed.), págs. 73-113.

-and Osgood, Ch. E., and Jenkins J.J. (1963), "Memorandum Concerning Language Universals», en Greenberg (ed.), págs. XVXXVII.

HALL-PARTEE, B. (1973), "Deletion and Variable Binding", en Keenan (ed.), págs. 16-34.

HUME, D. (1973), Del conocimiento. Buenos Aires, Aguilar.

JACKENDOFF, R.S. (1972), Semantic Interpretation in Generative Grammar. Cambridge de Mass, MIT Press.

JACOBS, R.A. and ROSENBAUM, P.S. (1968), English Transformational Grammar. New York, John Wiley and Sons, Inc.

JAKOBSON, R. (1963), "Implications of Language Universals for Linguistics», en Greenberg (ed.), págs. 263-279.

KATZ, J.J. (1966), La filosofia del lenguaje. Barcelona, Martínez Roca.

-and Postal, P.M. (1964), An Integrated Theory of Description Linguistic. Cambridge De Mass., MIT Press.

KEENAN, E.L. (ed.) (1975), Formal Semantics of Natural Languages: Papers from a Colloquium sponsored by the king's College Research Centre. Cambridge, Cambridge Univ. Press.

KIPARSKY, P. and KIPARSKY C. (1967), “Hechos», en Sánchez de Zavala (comp.), (II), 1976, págs. 31-76.

LAKOFF, G. (1965), Irregularity in Syntax. New York, Holt, Rinehart and Winston.

-(1966), "Gramática profunda y gramática superficial», en Sánchez de Zavala (comp.), (I), págs. 47-132.

- (1968), Pronouns and Reference. Bloomington, Indiana Univ. Ling. Club.

LANGACKER, R. W. (1966), "On pronominalization and the Chain of Command", en Reibel and Schane (eds.), págs. 160-186.

LANGENDOEN, D.T. (1969), The Study of Syntax. The GenerativeTransformational Approach to the Structure of American English. New York, Holt, Rinehart and Winston, Inc.

LEES, R.B. and Klima, E. (1963), "Rules for English Pronominalization", en Reibel and Schane (eds.), págs. 145-159.

LEIBNITZ, G.W. (1972a), Nuevo tratado sobre el entendimiento humano.

Buenos Aires, Aguilar.

-(1972b), Monadologia. Buenos Aires, Aguilar. 
LEIBNITZ, G.W. (1973), La profesión de fe del filósofo. Buenos Aires, Aguilar.

LILES, B. (1971), Ant Introductory to Transformational Grammar, New Jersey, Englewood Cliffs, Prentice-Hall, Inc.

LOCKE, J. (1974), Ensayo sobre el entendimiento humano. Buenos Aires, Aguilar.

LYONS, J. (1968), Introducción en la lingüistica teórica. Barcelona, Teide, 1971.

-(1970), Chomsky. Barcelona, Grijalbo, 1974.

LLEDO, E. (1970), Filosofía y lenguaje. Barcelona, Ariel.

McCAWLEY, J.D. (1967), «Meaning and the Description of Language», en Rosenberg and Travis (eds.), págs. 514-533.

- (1968a), "Where do Noun Phrases Come from?", en McCawley (1973), págs. 133-154.

-(1968b), "Lexical Insertion in a Transformational Gramar without Deep Structure», en McCawley (1973), págs. 155-166.

_(1969a), “English as a VSO Language», en McCawley (1973), págs. 211-228.

-(1969b), «Semantic Representation», en McCawley (1973), págs. 240-256.

- 1970), "A Program for Logic», en McCawley (1973), págs. 285-319.

- (1971), «Prelexical Syntax», en McCawley (1973), págs. 343-356.

- (1973), Grammar and Meaning. Tokio, Taishukan Publishing Company.

McNEILL, D. (1970), “Are there Specifically Linguistic Universals? », en Steinberg and Jakobovits (eds.), págs. 530-535.

OSGOOD, CH. E. (1963), "Language Universals and Psycholinguistics», en Greenberg (ed.), 1966, págs. 299-322.

POSTAL, P.M. (1968), Cross-Over Phenomena. New York, Rinehart and Winston, 1971.

-(1970), «On Coreferential Complements Subject Deletion», en Linguistic Inquiry, 1:4, págs. 439-500.

-(1972), On Raising. One Rule of English Grammar and its Theoretical Implications. Cambridge de Mass., MIT Press. 1974.

REIBEL, D.A. and SCHANE, S.A. (eds.) (1969), Modern Studies in English. Readings in Transformational Grammar. New Jersey, Englewood Clifs, Prentice-Hall, Inc.

RIVERO, M. ${ }^{a}$ L. (1977), Estudios de gramática generativa del español. Madrid, Cátedra.

ROGERS, A. (1971), "Tres tipos de verbos de percepción física", en Sánchez de Zavala (comp.) (II), págs. 141-163. 
ROSENBAUM, P.S. (1967), The Grammar of English Predicate Complement Constructions. Cambridge de Mass, MIT Press.

ROSENBERG, J.F. and TRAVIS, Ch. (eds.) (1971), Readings in the Philosophy and Language. New Jersey, Englewood Cliffs, PrenticeHall, Inc.

ROSS, J.R. (1966a), «A Proposed Rule of Tree-Pruning», en Reibel and Schane (eds.), págs. 288-299.

-(1966b), «Adjectives as Noun Phrases", en Reibel and Schane (eds.), págs. 352-360.

-(1966c), «Auxuliries as Main Verbs». Journal of Philosophical Linguistics, vol. I, número 1, págs. 77-102.

-(1967), "On the Cyclic Nature of English Pronominalization", en Reibel and Schane (eds.), págs. 187-200.

SANCHEZ DE ZAVALA, V. (comp). (I) (1974), Semántica y sintaxis en la lingüística transformatoria. Madrid, Alianza Universidad.

- (comp.) (II) (1976), Semántica y sintaxis en la lingüistica transformatoria. Madrid, Alianza Universidad.

SEARLE, J. (1969), Speech Acts. An Essay in the Philosophy of Language. Cambridge, Cambridge Univ. Press.

STEINBERG and JAKOBOVITS, L.A. (eds.) (1971), Semantics. An Interdisciplinary Reader in Philosophy, Linguistics and Psychology. Cambridge, Cambridge, Univ. Press.

ULMANN, S. (1963), “Semantic Universals”, en Greenberg (ed.), págs. 217-263.

WEINREICH, U. (1963), «On the Semantic Structure of Language», en Greenberg (ed.), págs. 142-216. 